\title{
Characterization of ozone profiles derived from Aura TES and OMI radiances
}

\author{
D. Fu ${ }^{1}$, J. R. Worden ${ }^{1}$, X. Liu ${ }^{2}$, S. S. Kulawik ${ }^{1}$, K. W. Bowman ${ }^{1}$, and V. Natraj ${ }^{1}$ \\ ${ }^{1}$ Earth and Space Sciences Division, Jet Propulsion Laboratory, California Institute of Technology, Pasadena, \\ California 91109, USA \\ ${ }^{2}$ Harvard-Smithsonian Center for Astrophysics, Cambridge, Massachusetts 02138, USA
}

Correspondence to: D. Fu (dejian.fu@jpl.nasa.gov)

Received: 21 August 2012 - Published in Atmos. Chem. Phys. Discuss.: 22 October 2012

Revised: 8 March 2013 - Accepted: 8 March 2013 - Published: 26 March 2013

\begin{abstract}
We present satellite based ozone profile estimates derived by combining radiances measured at thermal infrared (TIR) wavelengths from the Aura Tropospheric Emission Spectrometer (TES) and ultraviolet (UV) wavelengths measured by the Aura Ozone Monitoring Instrument (OMI). The advantage of using these combined wavelengths and instruments for sounding ozone over either instrument alone is improved sensitivity near the surface as well as the capability to consistently resolve the lower troposphere, upper troposphere, and lower stratosphere for scenes with varying geophysical states. For example, the vertical resolution of ozone estimates from either TES or OMI varies strongly by surface albedo and temperature. Typically, TES provides $1.6 \mathrm{de}-$ grees of freedom for signal (DOFS) and OMI provides less than 1 DOFS in the troposphere. The combination provides 2 DOFS in the troposphere with approximately 0.4 DOFS for near surface ozone (surface to $700 \mathrm{hPa}$ ). We evaluated these new ozone profile estimates with ozonesonde measurements and found that calculated errors for the joint TES and OMI ozone profile estimates are in reasonable agreement with actual errors as derived by the root-mean-square (RMS) difference between the ozonesondes and the joint TES/OMI ozone estimates. We also used a common a priori profile in the retrievals in order to evaluate the capability of different retrieval approaches on capturing near-surface ozone variability. We found that the vertical resolution of the joint TES/OMI ozone profile estimates shows significant improvements on quantifying variations in near-surface ozone with RMS differences of $49.9 \%$ and correlation coefficient of $R=0.58$ for the TES/OMI near-surface estimates as compared to $67.2 \%$ RMS difference and $R=0.33$ for TES
\end{abstract}

and $115.8 \%$ RMS difference and $R=0.09$ for OMI. This comparison removes the impacts of using the climatological a priori in the retrievals. However, it results in artificially large sonde/retrieval differences. The TES/OMI ozone profiles from the production code of joint retrievals will use climatological a priori and therefore will have more realistic ozone estimates than those from using a common a priori volume mixing ratio profile.

\section{Introduction}

The vertical distribution of ozone plays important roles in the Earth's atmosphere since the ozone filters out bio-damaging ultraviolet (UV) light (wavelength $<280 \mathrm{~nm}$ ) in the stratosphere, acts as a greenhouse gas in the upper troposphere, regulates the oxidation capacity of the lower atmosphere, and affects the air quality for humans and vegetation near the Earth's surface. About $90 \%$ of the total atmospheric ozone is in the stratosphere, with the remaining $10 \%$ in the troposphere where it acts as a greenhouse gas in the upper troposphere and as a pollutant near the surface. For example, exposure to ozone gas can harm lung function, irritate the respiratory system (World Health Organization, 2003; Bell et al., 2006) and increase the risk of death from respiratory causes (Weinhold, 2008; Jerrett et al., 2009). Ozone and pollution at ground level interfere with photosynthesis and stunt overall growth of plants and consequently can reduce agricultural yields (Hatfield et al., 2008).

Quantifying the vertical distribution of ozone is needed to investigate the mechanisms that control ozone concentration. 
In situ and remote sensing techniques have been used in the measurements of ozone vertical distributions. The ozonesonde (Komhyr et al., 1995) is a lightweight $(\sim 700 \mathrm{~g})$, compact $(19.1 \times 19.1 \times 25.4 \mathrm{~cm})$, balloon-borne, in situ instrument that provides measurements with a high vertical resolution $(\sim 150 \mathrm{~m})$ and accuracy $(\sim 5-10 \%)$ over regional scales. Remote sensing of ozone concentration using spectroscopic techniques has been performed using both UV and thermal infrared (TIR) measurements. The UV measurements were carried out from ground (Götz et al., 1934; McDermid et al., 2002; Petropavlovskikh et al., 2005; Tzortziou et al., 2008), aircraft (Browell et al., 1983), balloon (Weidner et al., 2005), and spaceborne platforms (nadir-viewing measurements by Solar Backscatter Ultraviolet Radiometer (SBUV) (Bhartia et al., 1996), Global Ozone Monitoring Experiment (GOME) (Munro et al., 1998; Hoogen et al., 1999; Liu et al., 2005, 2006), GOME-2 (van Peet et al., 2009; Cai et al., 2012), Ozone Monitoring Instrument (OMI) (Liu et al., 2010a; Kroon et al., 2011), and limbscattering measurements by Shuttle Ozone Limb Sounding Experiment (SOLSE) (McPeters et al., 2000), Optical Spectrograph and InfraRed Imager System (OSIRIS) (von Savigny et al., 2003), and SCanning Imaging Absorption SpectroMeter for Atmospheric CHartographY (SCIAMACHY) (Eichman et al., 2004; Sellitto et al., 2012a,b)). The TIR measurements were performed from ground (Pougatchev et al., 1995; Hamdouni et al., 1997), aircraft (Toon et al., 1989; Blom et al., 1995), balloon (Clarmann et al., 1993; Toon et al., 2002), and spaceborne platforms (Atmospheric Trace Molecules Observed by Spectroscopy (ATMOS) (Gunson et al., 1990); Cryogenic Limb Array Etalon Spectrometer (CLAES) (Bailey et al., 1996); HALogen Occultation Experiment (HALOE) (Brühl et al., 1996); CRyogenic Infrared Spectrometers \& Telescopes for the Atmosphere (CRISTA) (Riese et al., 1999); Atmospheric Chemistry Experiment (ACE) (Bernath et al., 2005; Boone et al., 2005), and Tropospheric Emission Spectrometer (TES) (Beer et al., 2001; Beer, 2006; Bowman et al., 2006); Infrared Atmospheric Sounding Interferometer (IASI) (Clerbaux et al., 2010)).

In the UV, the backscattered radiance spectra measured from space contain information on the vertical distribution of ozone because of the dependency of ozone absorption on wavelength and attenuation of UV through Rayleigh scattering (Chance et al., 1997). The ozone $v_{3}$ band around $9.6 \mu \mathrm{m}$ is useful for profiling atmospheric ozone distributions because the rotation-vibration resolved spectral lines of the $v_{3}$ band depend on pressure and temperature. Both TIR and UV sounders are able to provide information on tropospheric ozone concentration, although UV sounders show less vertical information in the troposphere and more vertical information in the stratosphere compared to IR sounders because the UV lines are less sensitive to temperature and pressure.

Recent studies point towards the potential of combining radiances measured in multiple spectral regions for increasing the vertical resolution of tropospheric trace gases. Wor- den et al. (2007b) performed synthetic retrievals for three instruments whose characterizations are similar to TES (Aura's Tropospheric Emission Spetrometer), OMI (Aura's Ozone Monitoring Instrument), and the combination of TES and OMI. The study demonstrated that estimating ozone profiles by combining UV (270-340 nm) and TIR (ozone band near $9.6 \mu \mathrm{m}$ ) radiances yields a factor of two or more improvement in the ability to resolve boundary layer ozone, compared with either instrument alone. In addition, there is a substantial improvement in the vertical resolution of ozone in the free troposphere (between $20 \%$ and $60 \%$ ) as compared to the TES vertical resolution. Landgraf and Hasekamp (2007) investigated the synergistic use of TIR (ozone band near $9.6 \mu \mathrm{m}$ ) and UV spectral region (290-320 nm) for the retrieval of vertical distribution of tropospheric ozone from satellite observations. The study also led to the conclusion that combining TIR and UV spectral ranges can improve significantly the retrieved ozone in the lowest $5 \mathrm{~km}$ of the troposphere. Using simulated measurements for 16 cloud and aerosol free atmospheric profiles spanning a range of ozone mixing ratios, Natraj et al. (2011) explored the feasibility of using multispectral intensity measurements in the UV, visible (VIS), mid-infrared (MIR) and TIR, also utilizing polarization measurements in the UV/VIS to improve tropospheric and lowermost tropospheric ozone measurements (surface to $2 \mathrm{~km}$ above surface). The analysis suggested that UV + VIS, UV + TIR and UV + VIS + TIR combinations have the potential to satisfy the measurement requirements (two degrees of freedom in the troposphere, and sensitivity from surface to $2 \mathrm{~km}$ ) of the GEOstationary Coastal and Air Pollution Events (GEO-CAPE) mission, a National Research Council recommended mission identified in "Earth Science and Applications from Space: National Imperatives for the Next Decade and Beyond" (National Research Council, 2007; Fishman et al., 2012).

In addition to the NASA GEO-CAPE mission, Japanese GMAP-Asia (Geostationary Meteorology and Air PollutionAsia, Akimoto et al., 2008) mission, Korea GEMS (Geostationary Environment Monitoring Spectrometer, Lee et al., 2010) mission, European GMES (Global Monitoring for Environment and Security) Sentinel-4 and Sentinel-5 missions (ESA, 2007; Lahoz et al., 2012; Ingmann et al., 2012) have been proposed for the air quality application. The Canadian PCW/PHEMOS-WCA (Polar Communication and Weather/Polar Highly Elliptical Molniya Orbital Science Weather, Climate and Air quality, McConnell et al., 2011) mission proposed to use UV-VIS-TIR spectrometers onboard two satellites, each in a highly eccentric orbit (apogee: $\sim 42000 \mathrm{~km}$; period: $12-24 \mathrm{~h}$ ) to provide air quality measurements over polar regions where GEOstationary (GEO) missions have poor coverage. The constellation of European, United States, Asian GEO missions and the Canadian PCW/PHEMOS-WCA mission provide global monitoring of air quality with proposed launch dates between 2017 to 2020 . These proposed GEO missions likely will use a multispectral 
approach such as the use of TIR together with other spectral regions (such as UV, VIS, NIR) to obtain near-surface estimates of $\mathrm{CO}$ and ozone.

In this paper, we explore the feasibility of estimating ozone using multiple spectral bands by using the measurements from the EOS Aura mission (one of NASA's Earth Observation System's satellites). In addition to our work, Cuesta et al. (2013) developed a multiple spectral retrieval algorithm on tropospheric ozone soundings using IASI and GOME-2, which simultaneously measured radiances from the MetOp satellite in the sun-synchronous orbit (local time of ascending node: 09:31 a.m.). Both this work and Cuesta et al. (2013) used identical spectral regions of the $v_{3}$ band in TIR and the Hartley and Huggins bands in the UV and showed similar vertical sensitivities and measurement uncertainties of ozone profile estimates.

The intuitive explanation of why multispectral satellite retrievals enhance near-surface sensitivity to trace gas concentrations is that the reflected UV sunlight radiances are sensitive to the tropospheric column whereas the TIR sounders are primarily sensitive to the free troposphere. The "subtraction" of the free tropospheric estimates from the total column estimates results in an estimate of near-surface concentrations. This "subtraction" must be performed using a non-linear retrieval for strongly varying trace gases such as ozone, as discussed here and in Worden et al. (2007), or CO (Worden et al., 2010), but can be performed linearly for weakly varying trace gases such as $\mathrm{CO}_{2}$ (Kuai et al., 2013).

In this paper, we show ozone profile results using radiance measurements from both the TES and OMI instruments. The paper is organized as follows: Sect. 2 describes the TES, OMI and ozonesonde measurements used in this work; Sect. 3 provides details of the retrieval algorithm; and Sect. 4 discusses the retrieval characterization of these multispectral retrievals, and shows examples of retrievals with a focus on tropospheric ozone and compares joint TES and OMI retrieval characteristics with those of using either instrument alone. Section 5 provides conclusions.

\section{TES, OMI, and ozonesonde measurements}

Both TES and OMI instruments are on the NASA Aura platform launched in 2004 in a near-polar, sun-synchronous, $705 \mathrm{~km}$ altitude orbit whose ascending node has a 13:38 equator crossing time.

\subsection{TES measurements}

TES is a Fourier transform spectrometer that measures radiances in the TIR $\left(650-3050 \mathrm{~cm}^{-1}\right)$ at a spectral resolution of $0.1 \mathrm{~cm}^{-1}$ for nadir viewing. A single TES nadir measurement takes 4 seconds and has a footprint size of $5.3 \mathrm{~km}$ (across track) $\times 8.5 \mathrm{~km}$ (along the spacecraft ground track). During each measurement, TES "stares" at the observation location, compensating for spacecraft motion. The TES instrument observes the Earths' TIR radiance in four spectral ranges using a separate array of detectors identified as $1 \mathrm{~A}$, $1 \mathrm{~B}, 2 \mathrm{~A}$, and 2B. TES atmospheric measurements of 1B2 $\left(950-1150 \mathrm{~cm}^{-1}\right)$ subregions have high-density absorption features of the ozone $v_{3}$ band (the strongest fundamental band) and minor absorption from interfering species, providing sensitivity for estimating atmospheric ozone volume mixing ratio (VMR). $\mathrm{H}_{2} \mathrm{O}$ absorption features spread across the TIR spectra and need to be taken into account when estimating ozone VMR. Therefore, TES 2A1 (1100-1325 cm-1) measurements were used to estimate $\mathrm{H}_{2} \mathrm{O}$ VMR. Table 1 lists the spectral windows that were used in our retrievals. TIR radiances in units of watts per square centimeter per steradian per inverse centimeter $\left(\mathrm{W} \mathrm{cm}^{-2} \mathrm{sr}^{-1} \mathrm{~cm}^{-1}\right)$ ), with associated estimates of random error named noise equivalent spectral radiance (NESR), were used in the retrievals. Both radiances and NESR were obtained from the processes of phase correction and radiometric calibration using TES level 1 algorithms (Worden et al., 2006). TES has two science-operating modes: Global Surveys (GS) and Special Observations (SO). GS are the observations that TES conducts approximately every two days and provides global measurements of atmospheric composition. The SO mode includes targeted measurements used for validation activities or to examine regional processes and emissions. Beer et al. (2001) and Beer (2006) described the TES instrument and data acquisition modes in detail. To obtain radiances that were taken co-located to OMI measurements, we used TES nadir measurements in either GS or SO mode over sonde sites.

\subsection{OMI measurements}

OMI is a nadir-viewing push broom ultraviolet-visible (UVVIS) imaging spectrograph that measures backscattered radiances covering the $270-500 \mathrm{~nm}$ wavelength range. The spectral range is divided into three subregions identified as UV-1 (270-310 nm), UV-2 (310-365 nm) and VIS (365$500 \mathrm{~nm}$ ). Retrievals presented in this paper used portions of the UV-1 (270-308 nm) and UV-2 (312-330 nm) spectral ranges, where the absorption features of the ozone Hartley and Huggins bands are clearly present in the spectra recorded by OMI. OMI has global measurement, spectral and spatial zoom-in modes. The ground pixel size at nadir position in the global mode (swath width about $2600 \mathrm{~km}$ ) is $13 \mathrm{~km}$ (along the ground track of spacecraft) $\times 24 \mathrm{~km}$ (across track) for the UV-2 and VIS channels, and $13 \mathrm{~km}$ (along the ground track of spacecraft) $\times 48 \mathrm{~km}$ (across track) for the UV-1 channel. Two UV-2 spectra are co-added to match the UV-1 spatial resolution. OMI zoom-in mode measurements are not included in this work due to lack of coincident TES and ozonesonde measurements. Row anomaly and stray light issues affect the quality of OMI measured radiance data. Since 2009, these instrument issues severely affected the OMI ground pixels, which were collocated to TES 
Table 1. Spectral Regions used in Joint TES and OMI Ozone Retrievals.

\begin{tabular}{|c|c|c|c|c|c|}
\hline Data Source & Optical Filter & Start Frequency & End Frequency & Point Spacing* & Atmospheric Species \\
\hline TES & 1B2 & $990.02 \mathrm{~cm}^{-1}$ & $1031.12 \mathrm{~cm}^{-1}$ & $0.06 \mathrm{~cm}^{-1}$ & $\mathrm{O}_{3}, \mathrm{H}_{2} \mathrm{O}, \mathrm{CO}_{2}$ \\
\hline TES & $1 \mathrm{~B} 2$ & $1044.08 \mathrm{~cm}^{-1}$ & $1049.06 \mathrm{~cm}^{-1}$ & $0.06 \mathrm{~cm}^{-1}$ & $\mathrm{O}_{3}, \mathrm{H}_{2} \mathrm{O}, \mathrm{CO}_{2}$ \\
\hline TES & 1B2 & $1068.98 \mathrm{~cm}^{-1}$ & $1071.38 \mathrm{~cm}^{-1}$ & $0.06 \mathrm{~cm}^{-1}$ & $\mathrm{O}_{3}, \mathrm{H}_{2} \mathrm{O}, \mathrm{CO}_{2}$ \\
\hline TES & $2 \mathrm{~A} 1$ & $1172.56 \mathrm{~cm}^{-1}$ & $1176.22 \mathrm{~cm}^{-1}$ & $0.06 \mathrm{~cm}^{-1}$ & $\mathrm{O}_{3}, \mathrm{H}_{2} \mathrm{O}, \mathrm{HDO}, \mathrm{CO}_{2}, \mathrm{CH}_{4}, \mathrm{~N}_{2} \mathrm{O}$ \\
\hline TES & $2 \mathrm{~A} 1$ & $1184.62 \mathrm{~cm}^{-1}$ & $1189.36 \mathrm{~cm}^{-1}$ & $0.06 \mathrm{~cm}^{-1}$ & $\mathrm{O}_{3}, \mathrm{H}_{2} \mathrm{O}, \mathrm{HDO}, \mathrm{CO}_{2}, \mathrm{CH}_{4}, \mathrm{~N}_{2} \mathrm{O}$ \\
\hline TES & $2 \mathrm{~A} 1$ & $1195.12 \mathrm{~cm}^{-1}$ & $1201.30 \mathrm{~cm}^{-1}$ & $0.06 \mathrm{~cm}^{-1}$ & $\mathrm{O}_{3}, \mathrm{H}_{2} \mathrm{O}, \mathrm{HDO}, \mathrm{CO}_{2}, \mathrm{CH}_{4}, \mathrm{~N}_{2} \mathrm{O}$ \\
\hline TES & $2 \mathrm{~A} 1$ & $1209.52 \mathrm{~cm}^{-1}$ & $1214.26 \mathrm{~cm}^{-1}$ & $0.06 \mathrm{~cm}^{-1}$ & $\mathrm{O}_{3}, \mathrm{H}_{2} \mathrm{O}, \mathrm{HDO}, \mathrm{CO}_{2}, \mathrm{CH}_{4}, \mathrm{~N}_{2} \mathrm{O}$ \\
\hline TES & $2 \mathrm{~A} 1$ & $1224.10 \mathrm{~cm}^{-1}$ & $1227.88 \mathrm{~cm}^{-1}$ & $0.06 \mathrm{~cm}^{-1}$ & $\mathrm{O}_{3}, \mathrm{H}_{2} \mathrm{O}, \mathrm{HDO}, \mathrm{CO}_{2}, \mathrm{CH}_{4}, \mathrm{~N}_{2} \mathrm{O}$ \\
\hline TES & $2 \mathrm{~A} 1$ & $1259.38 \mathrm{~cm}^{-1}$ & $1261.42 \mathrm{~cm}^{-1}$ & $0.06 \mathrm{~cm}^{-1}$ & $\mathrm{O}_{3}, \mathrm{H}_{2} \mathrm{O}, \mathrm{HDO}, \mathrm{CO}_{2}, \mathrm{CH}_{4}, \mathrm{~N}_{2} \mathrm{O}$ \\
\hline TES & $2 \mathrm{~A} 1$ & $1265.92 \mathrm{~cm}^{-1}$ & $1267.06 \mathrm{~cm}^{-1}$ & $0.06 \mathrm{~cm}^{-1}$ & $\mathrm{O}_{3}, \mathrm{H}_{2} \mathrm{O}, \mathrm{HDO}, \mathrm{CO}_{2}, \mathrm{CH}_{4}, \mathrm{~N}_{2} \mathrm{O}$ \\
\hline TES & $2 \mathrm{~A} 1$ & $1269.46 \mathrm{~cm}^{-1}$ & $1270.54 \mathrm{~cm}^{-1}$ & $0.06 \mathrm{~cm}^{-1}$ & $\mathrm{O}_{3}, \mathrm{H}_{2} \mathrm{O}, \mathrm{HDO}, \mathrm{CO}_{2}, \mathrm{CH}_{4}, \mathrm{~N}_{2} \mathrm{O}$ \\
\hline TES & $2 \mathrm{~A} 1$ & $1277.86 \mathrm{~cm}^{-1}$ & $1279.24 \mathrm{~cm}^{-1}$ & $0.06 \mathrm{~cm}^{-1}$ & $\mathrm{O}_{3}, \mathrm{H}_{2} \mathrm{O}, \mathrm{HDO}, \mathrm{CO}_{2}, \mathrm{CH}_{4}, \mathrm{~N}_{2} \mathrm{O}$ \\
\hline TES & $2 \mathrm{~A} 1$ & $1311.70 \mathrm{~cm}^{-1}$ & $1315.36 \mathrm{~cm}^{-1}$ & $0.06 \mathrm{~cm}^{-1}$ & $\mathrm{O}_{3}, \mathrm{H}_{2} \mathrm{O}, \mathrm{HDO}, \mathrm{CO}_{2}, \mathrm{CH}_{4}, \mathrm{~N}_{2} \mathrm{O}$ \\
\hline TES & $2 \mathrm{~A} 1$ & $1315.72 \mathrm{~cm}^{-1}$ & $1317.82 \mathrm{~cm}^{-1}$ & $0.06 \mathrm{~cm}^{-1}$ & $\mathrm{O}_{3}, \mathrm{H}_{2} \mathrm{O}, \mathrm{HDO}, \mathrm{CO}_{2}, \mathrm{CH}_{4}, \mathrm{~N}_{2} \mathrm{O}$ \\
\hline OMI & UV-1 & $270 \mathrm{~nm}$ & $308 \mathrm{~nm}$ & $0.32 \mathrm{~nm}$ & $\mathrm{O}_{3}$ \\
\hline OMI & UV-2 & $312 \mathrm{~nm}$ & $330 \mathrm{~nm}$ & $0.15 \mathrm{~nm}$ & $\mathrm{O}_{3}$ \\
\hline
\end{tabular}

* TES has a uniform spectral grid. The spectral point spacing of OMI is not constant and the mean value in the spectral region is listed.

measurements. For this reason, the TES and OMI joint retrievals shown in our study are for measurements from 2005 to 2008 .

\subsection{Ozonesonde measurements}

Ozonesonde measurements that provide in situ data from the surface to the stratosphere (about $35 \mathrm{~km}$ ) with vertical resolution of $\sim 150 \mathrm{~m}$ and accuracy of $\pm 5 \%$ fill a critical need for the validation of ozone profiles measured by TES and OMI instruments. The ozonesonde sensor has a dilute solution of potassium iodide to produce a weak electrical current proportional to the ozone concentration of the sampled air (Komhyr et al., 1995). To examine the performances of TES, OMI and sonde in capturing the variations of surface ozone concentration, we applied the following coincidence criteria to select sonde-TES-OMI pairs: mean cloud optical depth $<0.1$, distance among TES, OMI and sonde $<50 \mathrm{~km}$, and time difference $<1 \mathrm{~h}$. Using these criteria for the September 2004 to December 2008 timeframe, we obtained 22 sonde-TES-OMI measurement triads (Table 2).

\section{Joint TES and $\mathrm{OMI} \mathrm{O}_{3}$ retrievals}

\subsection{Radiative transfer calculation}

The retrieval strategy utilizes a non-linear least squares method to minimize the difference between observed and calculated spectral radiances subject to second-order statistical constraints on the variability of the atmospheric state (Bowman et al., 2002; Kulawik et al., 2006a). The critical requirements for a forward model is that it be as accurate as possible and be capable of performing the calculations with acceptable computational cost (Clough et al., 2006). The OMI ozone vertical profiles have been retrieved/validated by Liu et al. (2010a, b). To reduce the amount of effort to program and validate a new model for the TIR spectral region, the joint TES and OMI forward model uses the forward model component of the Earth Limb and Nadir Operational Retrieval prototype (IDL-ELANOR) to simulate spectral radiances and Jacobians (sensitivity of spectral radiance measured by the instrument to perturbations in retrieved parameters). In the UV spectral region, we use the Vector LInearized Discrete Ordinate Radiative Transfer (VLIDORT) model (Spurr, 2006, 2008), with configurations similar to those in Liu et al. (2010a), to compute the spectral radiances and Jacobians.

\subsubsection{Radiative transfer calculation for the TIR}

The TES operational retrieval algorithm simulates TIR spectral radiances using its forward model component and adjusts the state vector being estimated to minimize the differences between the measured spectral radiances and those obtained from the forward model subject to a priori constraints on the mean and covariance of the atmospheric state. The forward model component does line-by-line radiative transfer modeling, which includes upwelling atmospheric emission, downwelling and back-reflected atmospheric emission, and surface emission (Clough et al., 2006), as well as cloud properties (Kulawik et al., 2007; Eldering et al., 2008). It also simulates the characteristics of the TES instrument. It provides simulated radiances and Jacobians of the spectral radiances with respect to specified parameters.

The radiative transfer calculation in the forward model uses a 66-layer pressure grid at fixed pressure levels. The 
Table 2. Coincident measurements among TES, OMI, and Ozonesonde.

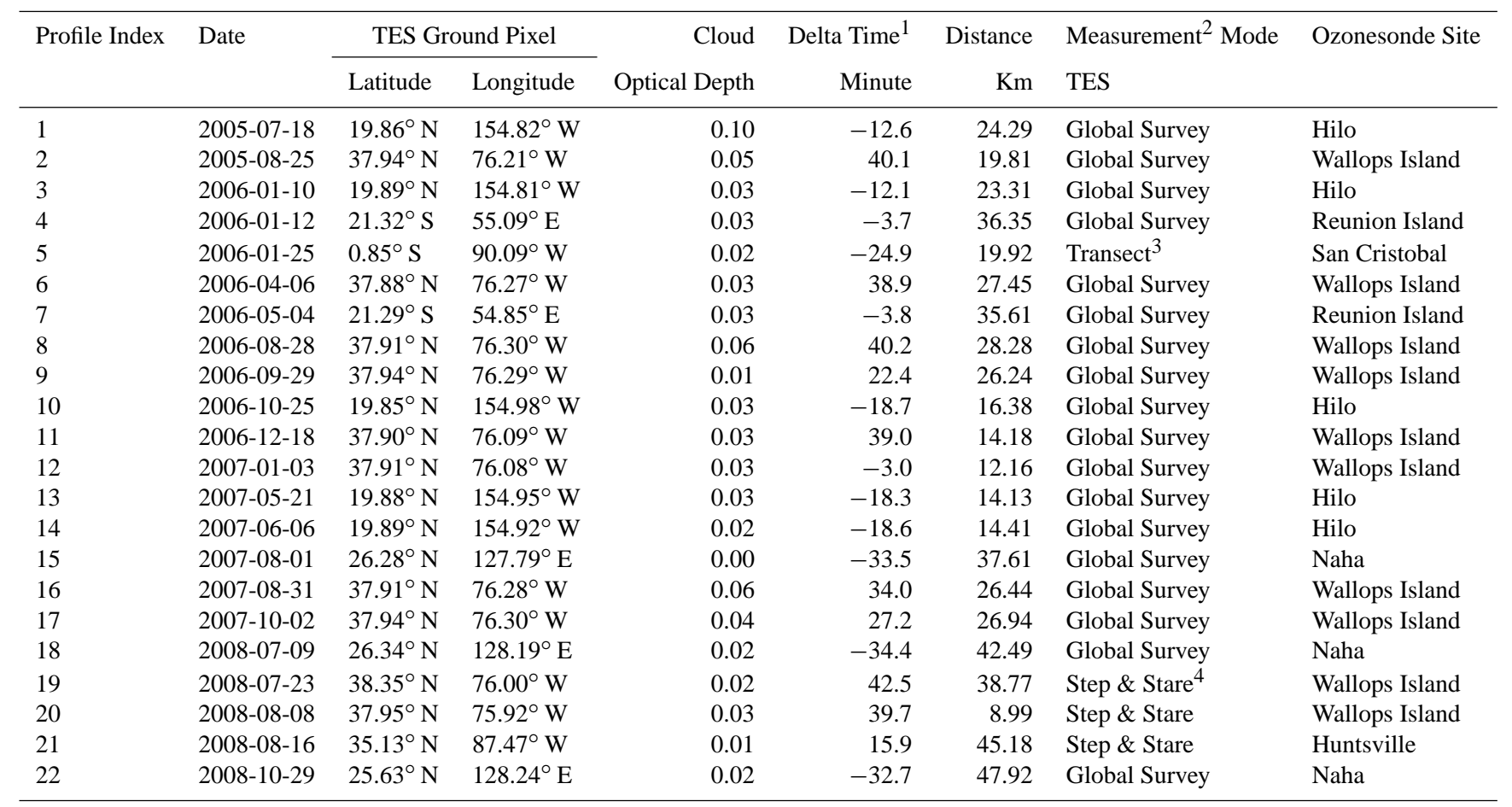

1 TES measurement time - Ozonesonde measurement time; time difference between collocated TES and OMI measurements is within seconds

2 All OMI measurements used here were taken from global measurement mode.

3 Transect: in nadir-viewing, point at a set of contiguous areas to cover about $850 \mathrm{~km}$. It is one of the settings used in TES special observations.

${ }^{4}$ Step \& Stare: point at nadir for $4 \mathrm{~s}$ (5.2 s with necessary reset). During that time, Aura moves $39 \mathrm{~km}$ in its orbit, and its nadir point on Earth's surface moves $35 \mathrm{~km}$. Point at nadir again. Repeat indefinitely. It is one of the settings used in TES special observations.

pressure at the Earth's surface provides the lower boundary for the forward model and is defined for every TES observation. The sea surface pressure is obtained from the Global Modeling and Assimilation Office (GMAO) GEOS-5 (Goddard Earth Observing System Model, version 5) model (Molod et al., 2012). The surface pressure is calculated from the sea surface pressure using the hydrostatic equation at the surface geodetic elevation. The top pressure boundary for the surface layer is a TES fixed pressure level.

For the simulation of ozone spectral radiances and weighting functions in the TIR spectral region (Table 1), we used the line positions, intensities and broadening parameters from Wagner et al. (2002). Those spectroscopic parameters have been used by the MIPAS mission (Flaud et al., 2003) and have been included in the HITRAN 2004 database (HIghresolution TRANsmission molecular absorption database) (Rothman et al., 2005, 2009). The accuracy of the line intensities is about $3 \%$.

For the TIR spectral region, the contribution of clouds in the radiative transfer modeling is parameterized in terms of a set of frequency-dependent nonscattering optical depths and a cloud top pressure (Clough et al., 2006; Kulawik et al., 2006b; Eldering et al., 2008). The model assumes clouds that are distributed about a single pressure level, which is de- noted by the cloud top pressure. These cloud parameters are retrieved jointly with surface temperature, emissivity, atmospheric temperature, and trace gases such as ozone from TES TIR spectral data.

\subsubsection{Radiative transfer calculation for the UV}

We used VLIDORT as the core of the forward model in the UV spectral region for the numerical computation of the Stokes vector in a multiple-scattering multilayer medium. This model uses the discrete ordinate method to approximate the multiple scatter integrals (Spurr, 2006, 2008). VLIDORT accounts for sphericity in the treatments of the incoming solar beam and outgoing beam attenuations. It calculates the Stokes parameters $I, Q, U$ and $V$ for a given model atmosphere, spectroscopic parameters and viewing geometry. For the calculations performed in this paper, VLIDORT was run in full-polarization mode. We expect that the effect of OMI instrument polarization sensitivity on the measured radiances is negligible since it utilizes a polarization scrambler to depolarize the measurement signal. The Jacobians with respect to the atmospheric trace gas concentration and surface properties are computed analytically by VLIDORT. Liu et al. (2010a) developed a retrieval algorithm, which uses VLIDORT as the forward model, to obtain $\mathrm{O}_{3}$ VMR profiles 
using OMI measurements. A single scattering model (Sioris and Evans, 2000) was used to simulate the Ring effect. For simulating radiances measured by OMI, we adopt the configurations that have been used in Liu's retrieval algorithm to optimize radiative transfer calculations in the UV spectral region.

The radiances were calculated for a Rayleigh atmosphere (no aerosols) with Lambertian reflectance assumed for the surface. We used the surface reflectance climatology constructed using $3 \mathrm{yr}$ of OMI measurements obtained between 2004 and 2007 (Kleipool et al., 2008). The surface albedo in UV-2 is wavelength-dependent and is represented as firstorder polynomials, which represent the surface effects and partly account for the presence of aerosols (similar to using climatological aerosols). Although higher-order polynomials can further reduce fitting residuals, they can adversely impact retrieval accuracy due to overly strong correlation with ozone. In the spectral region of interest, atmospheric $\mathrm{SO}_{2}$ and $\mathrm{BrO}$ absorption is typically much weaker than that of $\mathrm{O}_{3}$. They were not modeled or retrieved. This only slightly affects retrievals except for volcanic eruption conditions. Simulations and retrievals of $\mathrm{SO}_{2}$ and $\mathrm{BrO}$ will be added later, since there is adequate spectral information in our fitting window for these trace gases. High-resolution $(0.01 \mathrm{~nm})$ ozone cross sections (Brion et al., 1993) were used in the simulation, which had been found to significantly reduce fitting residuals in the Huggins band compared to other cross sections (Liu et al., 2007). The simulated high spectral resolution radiances and Jacobians were convolved with the OMI instrument slit function, which was computed using the hyper-parameterization parameters obtained during the onground calibration measurements (Dobber et al., 2006). To account for the temperature dependence of ozone absorption, we used temperature profiles from TES Version 4 products.

Clouds were treated as reflecting boundaries with a Lambertian reflectance whose surface albedo is 0.8 . Two sets of cloud products are available from OMI measurements. One set of cloud top pressure and cloud fraction was obtained using the $\mathrm{O}_{2}-\mathrm{O}_{2}$ absorption band near $477 \mathrm{~nm}$ (Acarreta et al., 2004) and the other set was retrieved using the effects of rotational Raman scattering (Joiner and Vasilkov, 2006; Vasilkov et al., 2008). Having two sets of OMI cloud products is to improve the temporal coverage of OMI cloud information since cloud information might not be available due to the quality control of cloud retrievals. Combining two sets of OMI cloud products increases the throughput of trace gas retrievals.

In the OMI-only retrievals (Liu et al., 2010a) and our work presented here, aerosols, clouds, and surface pressure were either not accurately known or were not modeled in the retrievals. In addition, OMI radiances need additional calibration corrections for profile retrievals. To account for these effects, we applied radiance calibration factors to the calculated radiances and fit wavelength-dependent surface albedo (i.e., zero order for UV-1, first-order polynomials for UV-2) as tuning parameters. The radiance calibration factors, which were taken from the work done by Liu et al. (2010a), were represented as a two-dimensional matrix defined by wavelength and OMI ground pixel index (across satellite ground track direction). The radiance calibration factors were derived by examining the averaged differences between OMI measured radiances and simulated radiances. OMI measurements over tropics were used in obtaining calibration factors since the spatio-temporal variability in ozone is smaller here than in other latitude regions. The OMI radiance simulations were made using the ozone profiles that were constructed as follows: zonal mean v2.2 ozone profiles (Livesey et al., 2008) from the microwave limb sounder (MLS, onboard Aura satellite) for pressure $<215 \mathrm{hPa}$, and climatological ozone profiles from McPeters et al. (2007) for pressure $>215 \mathrm{hPa}$. The radiance calibration factors show significant wavelength and cross-track dependencies together with discontinuities of 3$9 \%$ at $310 \mathrm{~nm}$ between UV-1 and UV-2.

There are a few differences in forward model settings between Liu et al. (2010a) and our work. VLIDORT can be run in scalar-mode only, i.e., without taking polarization into account, to reduce computation time. Liu et al. (2010a) performed scalar-only and full-polarization calculations at 12 selected wavelengths to derive polarization corrections at these wavelengths, and then interpolated the polarization corrections to the entire wavelength grid of the forward model. Next, they performed scalar-only calculations for the entire wavelength grid of the forward model and applied the polarization correction factors. Liu et al. (2010a) co-added five and two adjacent spectral pixels in UV-1 and UV-2, respectively, to speed up the retrievals. Neither co-adding adjacent spectral pixels nor simulating spectral radiances in scalar mode was applied in our retrieval algorithm because the number of coincident TES and OMI measurements is similar to that of TES measurements, which is about 100 times smaller than that of OMI. Liu's OMI forward model used the daily National Centers for Environmental Prediction (NCEP) reanalysis temperature profiles (Kalnay et al., 1996) with updated surface pressure derived from the topographical altitude of the OMI pixel by assuming a standard sea level pressure of $1 \mathrm{~atm}$ (Liu et al., 2010a). In our retrieval, we used temperature and trace gas concentration profiles from TES version 4 products for spectral simulations in both TIR and UV spectral regions.

\subsection{Optimal estimation retrievals}

The joint TES and OMI retrieval algorithm is based on the optimal estimation method (Rodgers, 2000; Bowman et al., 2002) that combines the a priori knowledge, which includes both a mean state and its covariance before the measurements are taken, and the information from combined TIR and UV measurements. The algorithm involves finding the best estimate state vector $\hat{z}$ by minimizing the cost function shown in Eq. (1): 
Table 3. List of fitting variables, a priori values and a priori errors.

\begin{tabular}{|c|c|c|c|c|}
\hline Case Selection $^{1}$ & Fitting Parameters & $\begin{array}{l}\text { Number of } \\
\text { Parameters }\end{array}$ & A Priori & A Priori Uncertainty \\
\hline TES+OMI, TES, OMI & $\mathrm{O}_{3}$ at each level & 25 & MOZART-3 & MOZART-3 $\sim 10-80 \%$ \\
\hline TES+OMI, TES & $\mathrm{H}_{2} \mathrm{O}$ at each level & 16 & GEOS4 & $\mathrm{NCEP} \sim 30 \%$ \\
\hline TES+OMI, TES & Surface temperature ${ }^{2}$ & 1 & GEOS4 & $0.5 \mathrm{~K}$ \\
\hline TES+OMI, TES & Surface emissivity ${ }^{2}$ & 32 & ASTER and land use map & $\sim 0.006$ \\
\hline TES+OMI, TES & Cloud extinction & 10 & Initial BT difference & $300 \%$ \\
\hline TES+OMI, TES & Cloud top pressure & 1 & $500 \mathrm{mbar}$ & $100 \%$ \\
\hline TES+OMI, OMI & UV-1 Surface Albedo & 1 & OMI climatology & 0.05 \\
\hline TES+OMI, OMI & UV-2 Surface Albedo (zero order term) & 1 & OMI climatology & 0.05 \\
\hline TES+OMI, OMI & First-order wavelength-dependent term for UV-2 & 1 & 0.0 & 0.01 \\
\hline TES+OMI, OMI & Ring scaling parameters & 2 & 1.9 & 1.00 \\
\hline TES+OMI, OMI & Radiance/irradiance wavelength shifts & 2 & 0.0 & $0.02 \mathrm{~nm}$ \\
\hline TES+OMI, OMI & Radiance $/ \mathrm{O}_{3}$ cross section wavelength shifts (zero order) & 2 & 0.0 & $0.02 \mathrm{~nm}$ \\
\hline TES+OMI, OMI & Radiance $/ \mathrm{O}_{3}$ cross section wavelength shifts (first order) & 2 & 0.0 & 0.004 \\
\hline TES+OMI, OMI & Cloud Fraction & 1 & Derived from $347 \mathrm{~nm}$ & 0.05 \\
\hline
\end{tabular}

${ }^{1}$ The parameters are included in the retrievals for different cases (TES only, OMI only, and TES and OMI).

${ }^{2}$ Retrievals over land, spectral surface emissivity and surface temperature are included.

$\chi^{2}=\left\|\mathbf{L}_{\mathrm{obs}}-\mathbf{L}_{\mathrm{sim}}(\hat{z})\right\|_{\mathbf{S}_{\varepsilon}^{-1}}^{2}+\left\|z-z_{\mathrm{a}}\right\|_{\mathbf{S}_{\mathrm{a}}^{-1}}^{2}$.

Equation (1) is a sum of quadratic functions representing the Euclidean distance, with the first term representing the difference between observed $\left(\mathbf{L}_{\mathrm{obs}}\right)$ and simulated radiance spectra $\left(\mathbf{L}_{\text {sim }}(\hat{z})\right)$ constrained by the measurement error covariance matrix $\left(\mathbf{S}_{\varepsilon}\right)$, and the second term accounting for the difference between retrieved $(\hat{z})$ and a priori $\left(z_{\mathrm{a}}\right)$ state vectors constrained by the a priori covariance matrix $\left(\mathbf{S}_{\mathrm{a}}\right)$. Note that $\|\mathbf{B}\|_{\mathbf{A}}^{2}$ means $\mathbf{B}^{\mathrm{T}} \mathbf{A B}$.

Table 3 lists the sources for the a priori vector and covariance matrix for those parameters that are being retrieved. The constraint matrix $\left(\mathbf{S}_{\mathrm{a}}^{-1}\right)$ in Eq. (1) is to regularize the illposed problem to obtain a stable solution that is an approximation to the exact solution. The standard constraints for atmospheric retrievals include climatology and Tikhonov constraints. The TES ozone retrievals use an altitude-dependent Tikhonov constraint matrix based on minimizing the expected error over an ensemble of retrievals (Steck, 2002; Kulawik et al., 2006c). The altitude-dependent Tikhonov constraint, which is different from the classic Tikhonov constraints, is composed of combinations of the zeroth-, first-, and second-order Tikhonov constraints with altitudedependent weights (Kulawik et al., 2006c). This procedure was adopted because the TES retrieval algorithm development team empirically found that low-thermal contrast conditions could result in many ozone retrievals showing unphysical results, or retrievals with significantly large errors, near the surface.

For the joint TES and OMI retrieval we used a constraint matrix based on a climatology generated using the MOZART3 (Brasseur et al., 1998; Park et al., 2004) ozone fields. The climatological constraint, which has been used by Worden et al. (2007b) in the theoretical study of combin- ing TIR and UV ozone observations, provides a weaker constraint than the altitude-dependent Tikhonov constraint matrix used in TES retrievals. This weaker constraint is justified because the OMI radiances provide increased sensitivity to stratospheric ozone and complimentary sensitivity (to TES) in the lower troposphere. In addition, we expect that the sensitivity of the OMI radiances to the total tropospheric ozone column, along with little sensitivity to thermal contrast variations, will stabilize the ozone estimates near the surface (see Sect. 4.1). For the OMI only retrievals, we used the same altitude-dependent Tikhonov constraint matrix for ozone as that of TES retrievals. We also tested the performances of TES retrievals using the climatological based constraint. Results for this comparison are discussed in more detail in Sect. 4.1; we found that, as expected, the DOFS improves for these TES ozone retrievals but the error also increases.

In addition to retrieving ozone concentration profiles (in volume mixing ratio or VMR), other geophysical parameters that affect the observed radiances such as surface albedo and emissivity, cloud properties, $\mathrm{H}_{2} \mathrm{O}$ and temperature must also be estimated. Instrument parameters such as OMI instrument wavelengths shifts must also be estimated for the $\mathrm{UV}$ radiances. These parameters and $\mathrm{H}_{2} \mathrm{O}$ concentrations are all simultaneously estimated, along with ozone, for the joint TES/OMI retrieval. However, in addition to the initial guess for the trace gas concentration, the initial guess for auxiliary parameters used in the simulation of TIR radiances (including surface temperature, surface emissivity, cloud extinction, cloud top pressure) were also obtained from TES Version 4 products in order to speed up the convergence of retrievals. Other parameters in the initial guess for the state vector were set equal to the a priori constraint vector (surface albedo, wavelength shifting parameters, cloud fraction). 

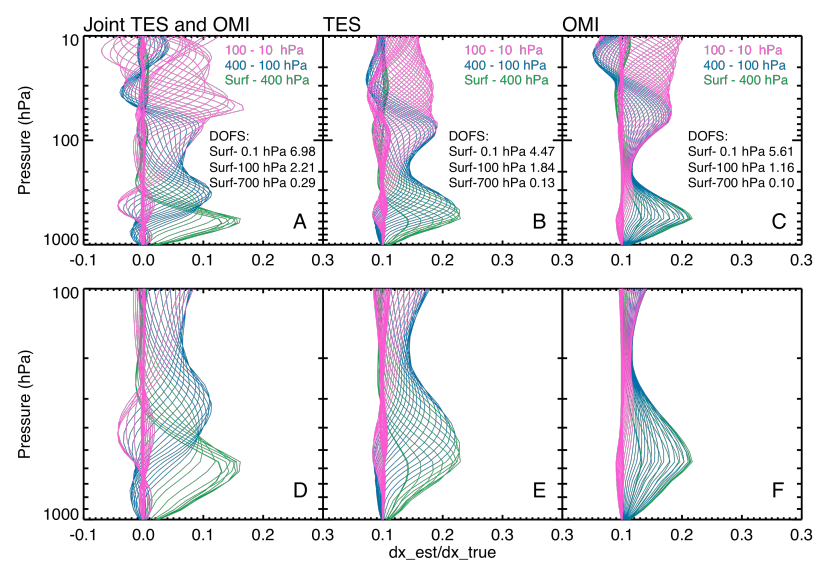

Fig. 1. Examples of averaging kernels for the measurement over Naha, Okinawa, Japan, on 1 August 2007: (A) Joint TES and OMI measurement; (B) TES measurement; (C) OMI measurement; (D, E, F) zoom-in view of averaging kernels from surface to $100 \mathrm{hPa}$. In each panel, averaging kernels in three altitude ranges are shown in color curves: surface to $400 \mathrm{hPa}$ in green; 400 to $100 \mathrm{hPa}$ in blue; and 100 to $10 \mathrm{hPa}$ in magenta. For Joint TES/OMI measurements, TES alone and OMI alone, DOFS in the altitude of surface to $700 \mathrm{hPa}$ is $0.29,0.13,0.10$, respectively; in the altitude of surface to $100 \mathrm{hPa}$ is $2.21,1.84,1.16$, respectively; and in the altitude of surface to $0.1 \mathrm{hPa}$ is $6.98,4.47,5.61$, respectively.

Retrievals typically converged within 3-4 iterations and with chi-square values (Eq. 1) close to 1 . A chi-square value of 1 indicates that the differences between observed and simulated radiances are within measurement noise level, and the differences between retrieved and a priori state vectors are within the a priori uncertainty.

\section{Results}

\subsection{Retrieval characterization example}

If the retrieval has converged and it can be shown that small changes in atmospheric state result in small and linear changes in the modeled radiances, then the estimated state vector $\hat{z}$ can be written as the linear expression (Rodgers, 2000):

$\hat{z}=z_{\mathrm{a}}+\mathbf{A}_{z}\left[z_{\text {true }}-z_{\mathrm{a}}\right]+\mathbf{G} \varepsilon+\delta_{\mathrm{cs}}$,

where $z_{\mathrm{a}}$ is the a priori constraint vector, $\mathbf{A}_{z z}$ is the averaging kernel matrix whose rows represent the sensitivity of the retrieval to the true state, $z_{\text {true }}$ is the true state vector, $\varepsilon$ is the spectral noise, and $\mathbf{G}$ is the gain matrix. The "cross-state" error, $\delta_{\mathrm{cs}}$, (Worden et al., 2007a) is incurred from retrieving multiple parameters (e.g., water vapor, surface temperature, cloud extinction and top pressure in TIR, cloud fraction in UV, surface albedo, and wavelength shifting parameters). The trace of the averaging kernel matrix gives the number of
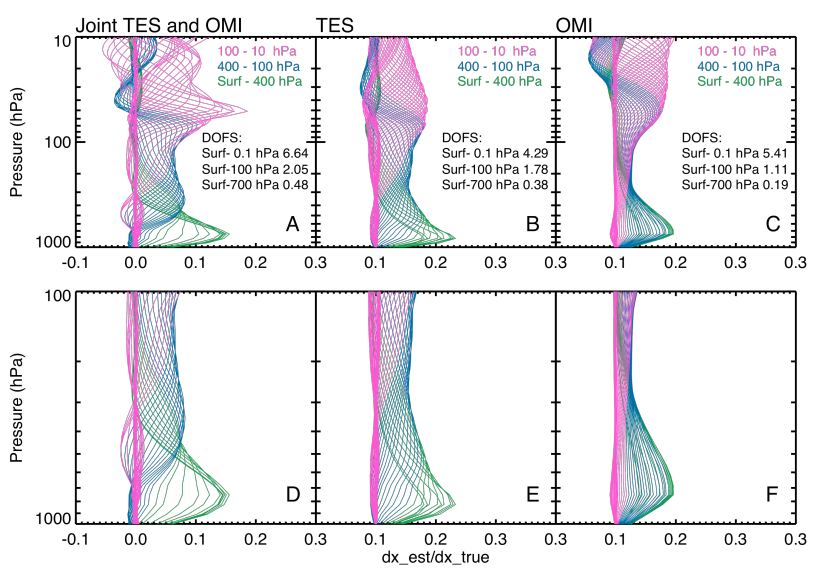

Fig. 2. Examples of averaging kernels for the measurement over Wallops Island, Virginia, USA, on 2 October 2007: (A) Joint TES and OMI measurement; (B) TES measurement; (C) OMI measurement; (D, E, F) zoom-in averaging kernels from surface to $100 \mathrm{hPa}$. In each panel, averaging kernels in three altitude ranges are shown in color curves: surface to $400 \mathrm{hPa}$ in green; 400 to $100 \mathrm{hPa}$ in blue; and 100 to $10 \mathrm{hPa}$ in magenta. For Joint TES/OMI measurements, TES alone and OMI alone, DOFS in the altitude of surface to $700 \mathrm{hPa}$ is $0.48,0.38,0.19$, respectively; in the altitude of surface to $100 \mathrm{hPa}$ is $2.05,1.78,1.11$, respectively; and in the altitude of surface to $0.1 \mathrm{hPa}$ is $6.64,4.29,5.41$, respectively.

independent pieces of information in the vertical profile, or, the degrees of greedom for signal (DOFS) (Rodgers, 2000). A larger DOFS value indicates a better sensitivity.

Figure 1 shows sample averaging kernel matrices for TES, OMI and joint TES and OMI observations over Naha, Okinawa, Japan, on 1 August 2007. These three measurements show different sensitivities to tropospheric ozone. TES can better resolve the lower/upper troposphere than OMI. Figure 1 shows the improvement in vertical resolution of tropospheric ozone by combining TES and OMI measurements. There is a clear enhancement of DOFS in the troposphere (TES only: 1.84; OMI only: 1.16; Joint TES and OMI: 2.21). The combined TES and OMI measurement also shows an increased sensitivity to the layer surface- $700 \mathrm{hPa}$. In addition to the spring/summer season when the thermal contrast is usually high, these improvements have been also observed during the fall/winter season (Fig. 2).

To validate the estimated ozone profiles, collocated ozonesonde measurements were compared to the estimated ozone profiles from TES only, OMI only, and joint TES and OMI measurements. The differences between the satellite retrievals and ozonesonde measurements smoothed by instrument averaging kernels can be written as expressed in Eq. (3) (Worden et al., 2007a):

$\Delta_{\text {satellite-sonde }}=\hat{z}-\hat{z}_{\text {sonde }}=\mathbf{A}_{z z}\left[z-z_{\text {sonde }}\right]+\mathbf{G} \varepsilon+\delta_{\mathrm{cs}}$,

where $\mathbf{A}_{z z}$ represents the averaging kernels of TES, OMI, or combined TES and OMI measurements. $\boldsymbol{z}, \mathbf{G}, \varepsilon$, and $\delta_{\mathrm{cs}}$ are 
the state vector, gain matrix, the noise of measured radiances, and cross state error, respectively. Equation (3) shows that the difference is not biased by the a priori constraint vector, $z_{\mathrm{a}}$, and can be used to identify other biases in ozone profiles estimated using satellite measurements (Eq. 4). The expected error for the differences between the satellite retrievals and ozonesonde measurements smoothed by instrument averaging kernels is

$$
\begin{gathered}
E\left[\left(\hat{z}-\hat{z}_{\text {sonde }}\right)\left(\hat{z}-\hat{z}_{\text {sonde }}\right)^{\mathrm{T}}\right] \\
=\underbrace{\mathbf{A}_{z z} \mathbf{S}_{\text {sonde }} \mathbf{A}_{z z}^{\mathrm{T}}}_{\begin{array}{l}
\text { ozonesonde } \\
\text { measurement } \\
\text { error }
\end{array}}+\underbrace{\mathbf{G S}_{\varepsilon} \mathbf{G}^{\mathrm{T}}}_{\begin{array}{l}
\text { satellite } \\
\text { instrument } \\
\text { measurement } \\
\text { error }
\end{array}}+\underbrace{\mathbf{A}_{\mathrm{cs}} \mathbf{S}_{\mathrm{cs}} \mathbf{A}_{\mathrm{cs}}^{\mathrm{T}}}_{\begin{array}{l}
\text { cross } \\
\text { state } \\
\text { error }
\end{array}},
\end{gathered}
$$

where $\mathbf{A}_{\mathrm{cs}}$ is the submatrix of the averaging kernel for the full state vector of all jointly retrieved parameters that relates the sensitivity of $z$ (the vector of cross-state parameters) to $z_{\mathrm{cs}}$ (corresponding cross-state a priori constraint vector) (Worden et al., 2007a), $\mathbf{S}_{\text {sonde }}$ is the sonde error covariance, $\mathbf{S}_{\varepsilon}$ is the spectral radiance measurement error covariance and $\mathbf{S}_{\mathrm{cs}}$ is the block diagonal matrix presented in Eq. (5). $\mathbf{S}_{\mathrm{cs}}$ contains the a priori covariance for the other jointly retrieved parameters including water vapor, surface temperature, surface emissivity, cloud parameters in infrared (extinction and cloud top pressure), surface albedo in UV, wavelength shifting in UV, and cloud parameter in UV (cloud fraction) parameters.

$\mathbf{S}_{\mathrm{cs}}=$

$\left(\begin{array}{cccccccc}\mathbf{S}_{\mathrm{H}_{2} \mathrm{O}} & 0 & 0 & 0 & 0 & 0 & 0 & 0 \\ 0 & \mathbf{S}_{\text {surf_TATM }} & 0 & 0 & 0 & 0 & 0 & 0 \\ 0 & 0 & \mathbf{S}_{\text {surf_emis }} & 0 & 0 & 0 & 0 & 0 \\ 0 & 0 & 0 & \mathbf{S}_{\text {cloud_IR }} & 0 & 0 & 0 & 0 \\ 0 & 0 & 0 & 0 & \mathbf{S}_{\text {surf_alb_UV }} & 0 & 0 & 0 \\ 0 & 0 & 0 & 0 & 0 & \mathbf{S}_{\text {ring_UV }} & 0 & 0 \\ 0 & 0 & 0 & 0 & 0 & 0 & \mathbf{S}_{\text {wls_UV }} & 0 \\ 0 & 0 & 0 & 0 & 0 & 0 & 0 & \mathbf{S}_{\text {cloud_UV }}\end{array}\right)$.

The differences between satellite measurements and in situ measurements (Eq. 3) arise from three sources: ozonesonde measurement error $(\sim \pm 5 \%$, Worden et al., 2007a), satellite measurement error $(\sim \pm 15-20 \%$ in the troposphere; $\sim \pm 5$ $10 \%$ in the stratosphere $)$, and cross-state error $(\sim \pm 15-20 \%$ in the troposphere; $\sim \pm 5-10 \%$ in the stratosphere). The sum of the last two terms is defined as observational error, which is the major contribution to the differences. Hence, for this analysis, we neglected the errors associated with the sonde measurements $( \pm 5 \%)$ since they are significantly smaller than the error terms of the satellite measurements. The typical altitude range of an ozonesonde measurement is from surface to above $10 \mathrm{hPa}$. The unmeasured part of the stratosphere is approximated by appending the ozone a priori VMR. We neglected the approximation in the stratosphere that is applied in some sonde cases since the effects to the troposphere are minor. In addition, the above error estimation assumes that both the satellite instruments and sonde measure the same atmospheric state (or airmass).
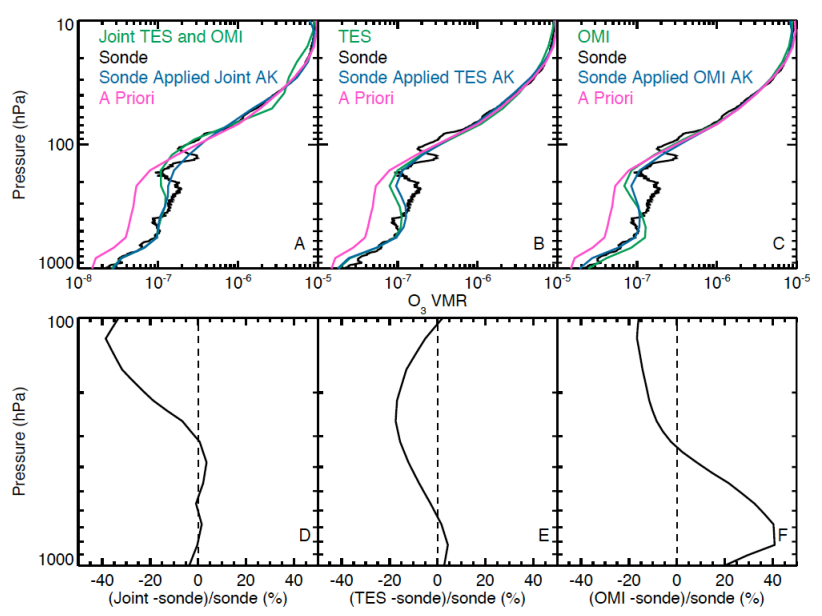

Fig. 3. Ozone volume mixing ratios measured by the instruments on Aura satellite and ozonesonde over Naha, Okinawa, Japan, on 1 August 2007. It is the same scenario as the one shown in Fig. 1. (A) Joint TES and OMI vs. Ozonesonde; (B) TES only vs. Ozonesonde; (C) OMI only vs. Ozonesonde; (D) percentage differences between joint retrieval and co-located sonde measurements; (E) percentage differences between TES retrieval and co-located sonde measurements; and (F) percentage differences between OMI retrieval and co-located sonde measurements. In (A), (B) and (C), retrieved profiles are in green; ozonesonde measurements are in black; ozonesonde profiles smoothed by averaging kernels of TES or OMI are in blue; and a priori are in magenta.

Figures 3 and 4 show the ozone concentration profiles measured by sonde, TES and OMI instruments over Naha, Okinawa, Japan, on 1 August 2007 and Wallops Island, Virginia, USA, on 2 October 2007, respectively. Both the sonde profiles smoothed by the averaging kernels of the satellite instruments (blue lines) and the estimated profiles (green lines) closely match the original ozonesonde measurements (black lines) and differ from the a priori profiles (magenta). Among the three sets of satellite measurements, the estimation using joint TES and OMI radiances has the smallest differences to the in situ measurements, indicating enhanced sensitivities and reduced uncertainties in the measurements, especially in the altitude range from the surface to about $300 \mathrm{hPa}$.

In the altitude range of $300 \mathrm{hPa}$ to $100 \mathrm{hPa}$ (Figs. 3 and 4), the joint TES and OMI retrievals show larger errors than the TES-only or OMI-only measurements. The current discrepancy between UV and TIR spectroscopic parameters together with the radiometric calibration consistency among different spectral regions are two major systematic error sources that might affect the accuracy of joint TES and OMI retrievals. In addition, the contribution of these two error sources can depend on pressure or temperature variations and hence altitude. The spectral discrepancy between UV and TIR is generally about $5.5 \%$ (Picquet-Varrault et al., 2005). The actual effect of the inconsistent UV and TIR spectroscopic parameters and radiometric calibrations is much less than the 

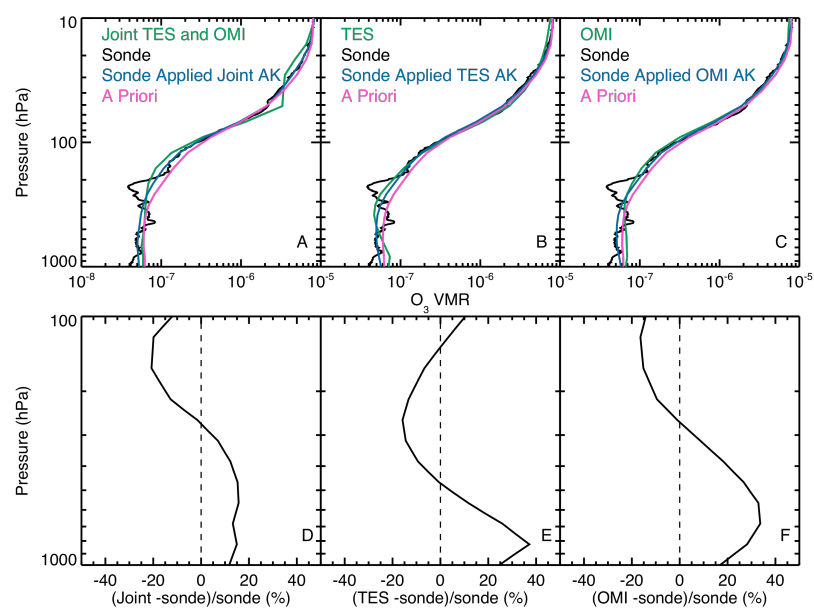

Fig. 4. Ozone volume mixing ratios measured by the instruments on Aura satellite and ozonesonde over Wallops Island, Virginia, USA, on 2 October 2007. It is the same scenario as the one shown in Fig. 2. (A) Joint TES and OMI vs. Ozonesonde; (B) TES only vs. Ozonesonde; (C) OMI only vs. Ozonesonde; (D) percentage differences between joint retrieval and co-located sonde measurements; (E) percentage differences between TES retrieval and co-located sonde measurements; and (F) percentage differences between OMI retrieval and co-located sonde measurements. In (A), (B) and (C), retrieved profiles are in green; ozonesonde measurements are in black; ozonesonde profiles smoothed by averaging kernels of TES or OMI are in blue; and a priori are in magenta.

predicted impacts shown in a previous study (Kulawik et al., 2007), possibly because fitting the surface albedo parameters in the UV spectral region provides a zero order correction to the radiometric calibration inconsistency (if there is any) between the TIR and UV spectral regions. In addition, we applied the wavelength-dependent radiance calibration factors to the OMI measurements prior to the joint TES and OMI retrievals. Those radiance calibration factors were derived and validated by Liu et al. (2010a) for the OMI retrievals. The retrieved profiles from joint retrievals do not show obvious unphysical oscillations (Figs. 3 and 4), which usually appear when inconsistency of spectroscopic parameters and the radiometric calibrations between TIR and UV spectral region severely affects the retrievals.

We next evaluated the bias and precision of each retrieval by showing comparisons between TES, OMI, and the joint TES/OMI ozone profile estimates with all 22 sondes for the altitude range between the surface and $700 \mathrm{hPa}$ as well as from 700 to $100 \mathrm{hPa}$. As discussed previously, the joint TES/OMI retrievals used a climatological constraint with relaxed sensitivity near the surface and the OMI and TES retrievals used a Tikhonov-like constraint. The corresponding averaging kernel and constraint vector were applied to the ozonesonde profile prior to comparison in order to remove the effect of the retrieval regularization on the comparison. Figure 5 shows the bias and precision for joint

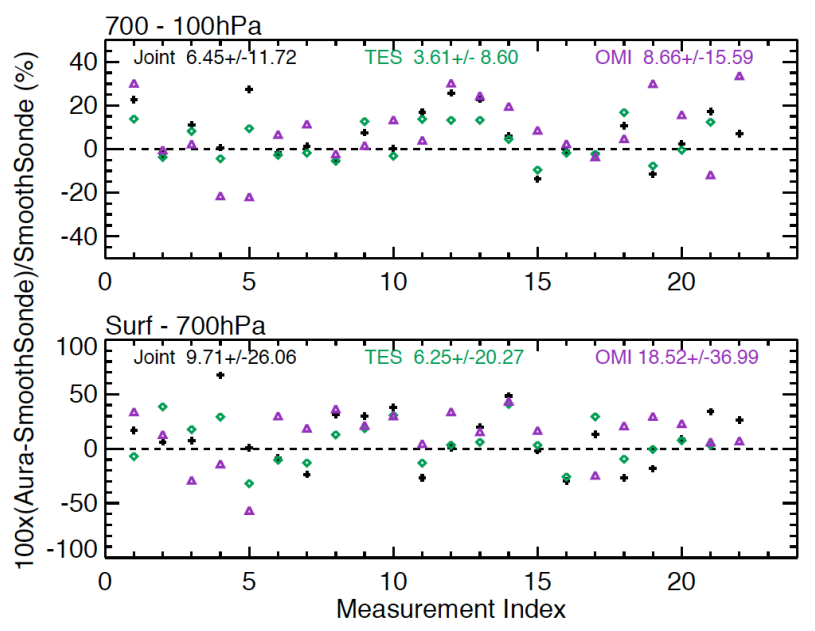

Fig. 5. Percentage differences between coincident Aura measurements and ozonesonde measurements in the troposphere: joint TES and OMI (black pluses), TES only (green diamonds), OMI only (purple triangles). The joint TES and OMI retrievals used the constraint matrix created from the MOZART3 ozone climatological covariance. The TES only and OMI only used an altitude-dependent Tikhonov constraint matrix. A priori ozone profile varies for each scene. Each scene listed in Table 2 is identified by the measurement index in the x-axis. The averaging kernels of Aura measurements were applied to the ozonesonde measurements.

TES/OMI, TES and OMI alone measurements. The bias of joint TES/OMI, TES alone and OMI alone is $9.71 \%, 9.04 \%$ and $18.52 \%$, respectively. The precision is $26.06 \%, 23.71 \%$ and $36.99 \%$, respectively.

The predicted precision for the TES/OMI estimates for the altitude range of $300 \mathrm{hPa}$ to $100 \mathrm{hPa}$ is $20.8 \%$ as compared to the actual precision of $26.06 \%$; however, a lower calculated precision was expected due to the non-linearity of the retrieval. For example, Boxe et al. (2010) found that the vertical distribution of the calculated TES ozone precision is consistent with the actual precision (as determined through comparison with ozonesondes) but is always larger by an amount that varies between $1 \%$ to $10 \%$. For the $700 \mathrm{hPa}$ to $100 \mathrm{hPa}$ region, all instruments show similar capability. The actual precision for the TES/OMI estimates is $6.5 \% \pm 11.7 \%$ and the calculated precision is $11.5 \%$. We note that these precisions do not describe how well each retrieval can resolve variations in tropospheric ozone because the averaging kernel has been applied to the sondes prior to comparison. We performed comparisons in the next section that test the capability of each retrieval for resolving variations at each altitude.

The previous comparisons used different constraint matrix of ozone concentration. A climatological constraint was used for the joint TES/OMI retrievals whereas a Tikhonovlike constraint was used for the TES and OMI retrievals. Theoretically, use of a climatological constraint will increase 


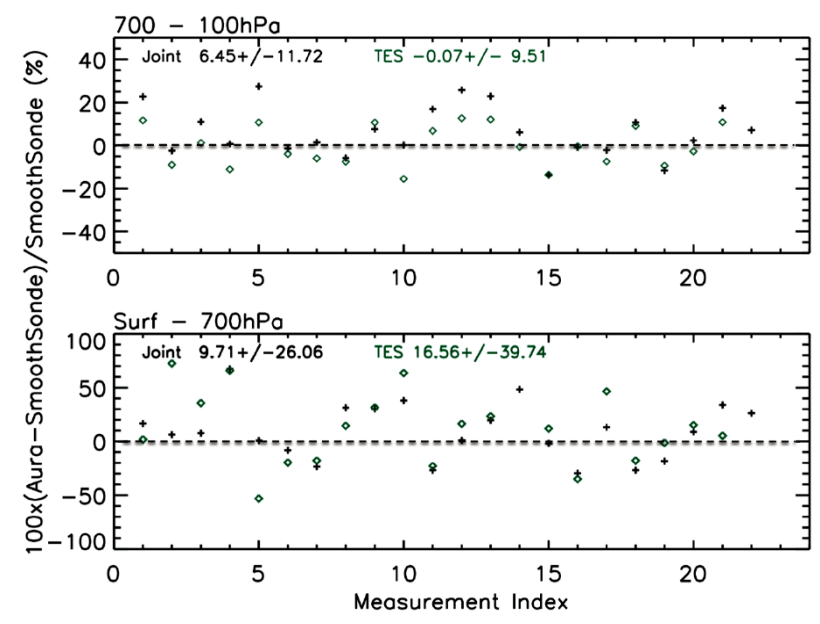

Fig. 6. Percentage differences between Aura measurements and ozonesonde measurements in the troposphere: Joint TES and OMI (black pluses), TES only (green diamonds). The TES only together with joint TES and OMI retrievals use the constraint matrix created from the MOZART3 ozone climatological covariance. Each scene listed in Table 2 is identified by the measurement index in the $\mathrm{x}$-axis. A priori ozone profile varies for each scene. The averaging kernels of Aura measurements were applied to the ozonesonde measurements.

the sensitivity of the TES and OMI retrievals to near-surface ozone concentrations; however, as discussed earlier, the constraint used for the TES retrievals was designed to reduce error in the lower troposphere resulting from degeneracy between thermal contrast, surface emissivity, and near-surface ozone variations. We next tested whether this climatological constraint could increase the information content of the TES retrievals. We found that the DOFS in the lower troposphere increases but the error in the retrieval increases as well. For example, Fig. 6 shows that the bias increases but the precision in the lower troposphere decreases from $9 \% \pm 23.7 \%$ to $16.56 \% \pm 39.7 \%$. This test showed that the joint OMI/TES retrieval indeed increases both the sensitivity and information content of near-surface ozone estimates over TES retrievals alone. We did not apply this test to the OMI retrievals because the OMI ozone retrievals cannot resolve different parts of the troposphere.

\subsection{Comparisons of ozone observations among TES, OMI, joint TES and OMI, ozonesonde}

Figure 7 shows the improvement in sensitivity to ozone for those TES-OMI pairs that spatio-temporally coincided with the ozonesonde measurements (Table 2). We calculated the DOFS between the surface and $700 \mathrm{hPa}$ (Fig. 7, bottom panel) to estimate the sensitivity of the ozone estimate to ozone near surface. The sensitivity improvement by combining TES and OMI radiances ranges from $30 \%$ to about a factor of 3, compared to each instrument alone. When com-

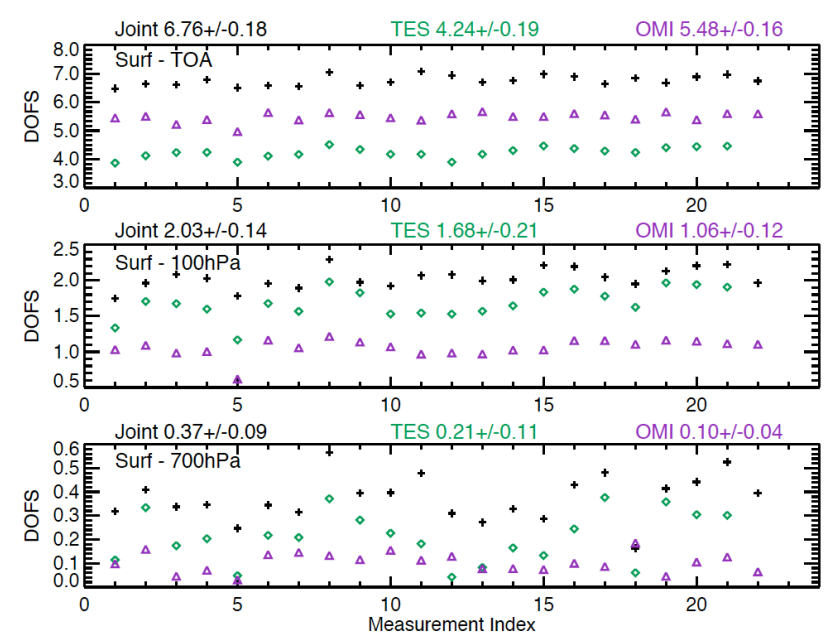

Fig. 7. DOFS for the set of ozone measurements in Table 2: (top panel) total DOFS; (middle panel) DOFS for the region between the surface and $100 \mathrm{hPa}$; (bottom panel) DOFS for the region between surface to $700 \mathrm{hPa}$; Joint OMI and TES (black pluses); TES (green diamonds); OMI (purple triangles). Each scene listed in Table 2 is identified by the measurement index in the x-axis. For Joint TES/OMI measurements, TES alone and OMI alone, the mean DOFS in the altitude of surface to $700 \mathrm{hPa}$ is $0.37,0.21,0.10$, respectively; in the altitude of surface to $100 \mathrm{hPa}$ is $2.03,1.68,1.06$, respectively; in the altitude of surface to $0.1 \mathrm{hPa}$ is $6.76,4.24,5.48$, respectively; the $1 \sigma$ standard deviation of the mean DOFS in the altitude of surface to $700 \mathrm{hPa}$ is $0.09,0.11,0.04$, respectively; in the altitude of surface to $100 \mathrm{hPa}$ is $0.14,0.21,0.12$, respectively; and in the altitude of surface to $0.1 \mathrm{hPa}$ are $0.18,0.19,0.16$, respectively.

bining both TIR and UV radiances to estimate the ozone concentration, the differences in the sensitivity characteristics between TES and OMI measurements enhance the capability of distinguishing the middle tropospheric ozone from the lower tropospheric ozone. TES averaging kernels present two peaks (Figs. 1 and 2), one in the lower/middle troposphere and the other in the lower stratosphere. In the troposphere, the peak altitudes of TES averaging kernels slightly vary with pressure level while OMI averaging kernels almost do not change. In addition, TES has stronger sensitivity in the middle and upper troposphere, compared to that of OMI. The peaks of the averaging kernel present an altitude offset between TES and OMI observations. TES is strongly peaked in the lower/middle troposphere, whereas the OMI averaging kernels have peak sensitivity typically below the altitude where the TES ozone estimate is most sensitive. This offset helps the combination of TES and OMI better distinguish near surface ozone. The middle panel of Fig. 7 shows the DOFS for the region between the surface and $100 \mathrm{hPa}$ and indicates that the improvement in vertical resolution for this set of scenes ranges between $20 \%$ and $60 \%$. The major part of the improvement appears in the free troposphere below $300 \mathrm{hPa}$, where TES and OMI averaging kernels show 


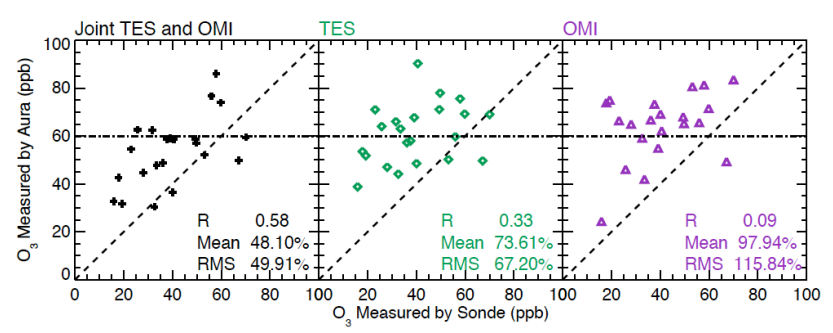

Fig. 8. Correlations of Aura measured and ozonesonde measured ozone concentration in parts-per-billion ( $\mathrm{ppb}$ ) in the region from surface to $700 \mathrm{hPa}$ : joint TES and OMI (left panel); TES only (middle panel); OMI only (right panel). For Joint TES/OMI measurements, TES alone and OMI alone, the mean difference is $48.10 \%$, $73.61 \%$, and $97.94 \%$, respectively; the $1 \sigma$ standard deviation to the mean difference is $49.91 \%, 67.20 \%$, and $115.84 \%$, respectively; and the correlation coefficient of $R$ is $0.58,0.33$, and 0.09 , respectively. The joint observations have improved the capability of capturing the variations of ozone concentration in the region from surface to $700 \mathrm{hPa}$, compared to TES or OMI observations alone. A common a priori ozone profile (horizontal dash line) was used in the retrievals for all of the scenes. The black dotted dash line indicates one-to-one correlation. The averaging kernels of the Aura measurements were not applied to the ozonesonde measurements.

the greatest sensitivity to tropospheric ozone (Figs. 1 and 2). Figure 7 presents the DOFS from three altitude ranges: top panel - surface to the top of atmosphere, middle panel - troposphere, and bottom panel - surface to $700 \mathrm{hPa}$ ) for three different measurement approaches. TES shows better sensitivity in the troposphere than OMI since the DOFS of TES measurements are larger than those of OMI (Fig. 7 middle panel) in the troposphere, whereas in the stratosphere the OMI observations show better sensitivity than TES as indicated from the differences in DOFS between top and middle panels in Fig. 7. When combined TES and OMI radiances are used in the retrievals, DOFS are enhanced in both the troposphere and the stratosphere; additionally, there is improved separation between the tropospheric and stratospheric ozone compared to using each instrument alone.

To further investigate the improvements on the tropospheric ozone sounding using both TIR and UV bands, we ran retrievals using a common a priori ozone profile for all of the scenes in Table 2 and compared the estimated ozone concentration to the ozonesonde measurements. Using a fixed a priori profile helps interpret the variability of the retrieved ozone profiles. The combined TES and OMI measurements (Figs. 8-9) show a better correlation with the ozonesondes than the TES or OMI measurements alone. Further, the root mean square of fractional differences between retrievals and sonde measurements are significantly reduced (by about a factor of 2) compared to either TES or OMI measurements alone, indicating that the combined retrievals have better capability to capture the $\mathrm{O}_{3}$ variation near the surface.

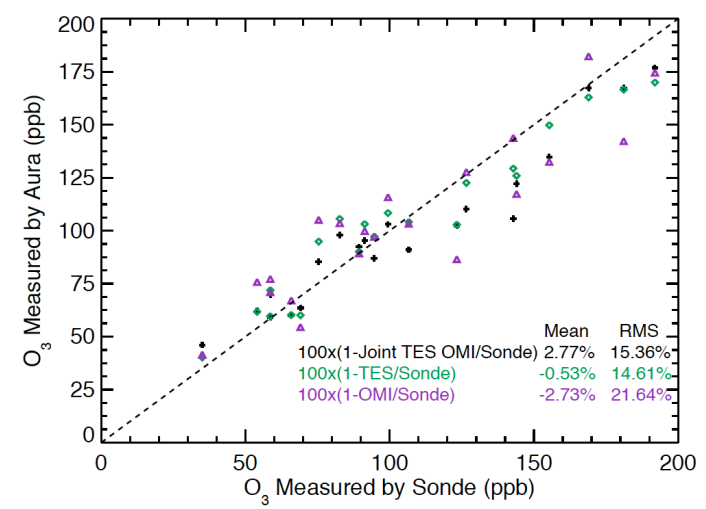

Fig. 9. Correlations of Aura measured and ozonesonde measured ozone concentration in parts-per-billion (ppb) in the region from $700 \mathrm{hPa}$ to $100 \mathrm{hPa}$ : Joint OMI and TES (black pluses); TES (green diamonds); OMI (purple triangles). For joint TES/OMI measurements the mean differences of $2.8 \%$ and $1 \sigma$ standard deviation to mean differences of $15.4 \%$; for TES measurements alone, $-0.5 \%$ and $14.6 \%$; for OMI measurements alone, $-2.7 \%$ and $21.6 \%$. The discrepancy between joint observations and sonde measurements is larger (mean: $1.24 \%$; RMS: $0.75 \%$ ) than that between TES only measurements and sonde measurements. Both joint observations and TES only measurements show better agreement to sonde measurements than OMI only measurements. A common a priori ozone profile was used in the retrievals for all of the scenes. The averaging kernels of Aura measurements were not applied to the ozonesonde measurements.

\subsection{Further algorithm improvements}

Joint TES and OMI retrievals exhibit enhanced sensitivity to ozone throughout the entire altitude range. It is worth noting that sensitivity to ozone near surface has not been fully exploited from the joint TES and OMI measurements due to the retrieval dependencies with other ancillary parameters, especially for the wavelength-dependent surface albedo (OMI) and emissivity (TES) parameters together with cloud fraction (OMI). Similar to the retrieval algorithm developed by Liu et al. (2010a), in the OMI UV-2 spectral region $(312-330 \mathrm{~nm})$ we fit a first-order wavelength dependent surface albedo term, which correlates (correlation coefficient $0.2-0.5$ ) with ozone concentration parameters, especially in the troposphere. On the other hand, this parameter is needed in the retrieval to account partly for spectral signatures of aerosol, clouds and calibration and helps to reduce fitting residuals. To reduce the correlation between surface albedo and ozone concentration parameters and improve the retrieval accuracy, we plan to implement a two-step approach in the retrieval algorithm: first, we will retrieve surface albedo (a priori uncertainty: zero order term 0.05, first order term 0.01 ) and other ancillary parameters from the OMI ground pixels adjacent to those being used in the joint TES and OMI observations; second, retrieved ancillary parameters from the first step will then be used as initial guess 
along with an a priori constraint vector with reduced a priori uncertainties (e.g, a priori uncertainty of surface albedo: zero order term 0.01 , first order term 0.002) to estimate ozone concentration using combined TES and OMI measured radiances. Reducing the a priori uncertainty decreases the correlation between ancillary parameters and ozone concentration parameters. It also decreases the correlation among ancillary parameters between surface albedo terms and cloud fraction, and between zero-order and first-order radiance/ozone crosssection wavelength shifts in both UV-1 and UV-2.

Our joint retrieval algorithm utilizes spatio-temporally coincident measured spectral radiances to retrieve the vertical distribution of ozone concentration. The spectral radiances from 312 to $330 \mathrm{~nm}$ were co-added using measurements over two OMI UV-2 ground pixels prior to the spectral fitting, yielding a group pixel size of $13 \times 48 \mathrm{~km}^{2}$ (along ground track $\times$ cross ground track of spacecraft) at Nadir. The coaddition approach, which has been used by Liu et al. (2010a) in OMI retrievals, helps in reducing forward model computation time compared to simultaneously fitting UV-2 spectra that represent these ground pixels. It also ensures both OMI UV1 and UV2 measurements probing common air volume, despite introducing minor spectral wavelength registration artifacts. A TES measurement at Nadir yields a ground pixel size of $8.5 \times 5.3 \mathrm{~km}^{2}$ (along ground track $\times$ cross ground track of spacecraft). We expect that the differences on the size of ground pixels between TES and OMI measurements do not significantly affect the retrieved ozone VMR since the measurements of using TIR spectral region show most sensitivities over/above free troposphere where the spatial gradient of ozone concentration is weak.

This work focused on investigating the feasibility of multiple spectral observations of near surface ozone concentration, evaluating the performances using measured radiances from current satellite instruments and providing realistic advance studies for the future missions. Hence, the scenarios shown in this work are in nearly clear sky conditions, in which the cloud fraction in each instrument's field of view is less than $10 \%$. We retrieved cloud parameters for each instrument in order to account for the differences on the instrument's field of view. Since both a priori values and initial guess values were taken from TES standard products and OMI standard products, the jointly retrieved values are generally within $1 \%$ compared to the products from each instrument alone. When processing the entire TES and OMI measured radiances that were recorded from 2005 to 2008, we decided to filter out those scenes whose cloud fractions are greater than $30 \%$ by using existing OMI released cloud products. We expect that the future satellite missions can achieve improvements on harmonizing the ground pixel sizes between TIR and UV bands. For instance, reducing the ground pixel sizes of UV bands improves the number of cloud free scenes since both OMI and GOME-2 provide larger ground pixels than TIR sounders onboard its common satellite platform.
The estimated discrepancies of spectroscopic parameters between TIR and UV spectral regions used in this work are up to $3 \%$, which is smaller than the estimated measurement uncertainties (Fig. 5) and ozone natural variations near surface. To further improve the quality of ozone measurements using multiple spectral regions, next generation of ozone spectroscopic parameters should mitigate the existing discrepancies among different spectral regions (microwave, thermal infrared, visible and ultraviolet). Prior to the availability of the new ozone cross-sections that mitigate the existing discrepancy ( $3 \%$ ) between UV and TIR spectroscopic parameters, we will implement an alternative correction to the forward model or retrieval, such as retrieving or applying a fixed line strength correction factor to address the discrepancy of the spectroscopic parameters.

\section{Conclusions}

We have provided a demonstration of the first coincident multispectral retrievals of ozone using both UV and TIR measured radiances from space. Improvements in both error characteristics and vertical resolution compared to those without using multispectral retrievals were shown. This technique allows for vertical ozone profiling with an average of 4.36 DOFS in the stratosphere, 2.03 DOFS in the troposphere, and with sensitivity to the planetary boundary layer (DOFS 0.37) for a wide variety of geophysical conditions. The typical precision for a single target near-surface estimate of ozone is approximately $26 \%$ (15.6 parts-per-billion (ppb)) with a bias of approximately $9.6 \%$ (5.7 ppb). Comparison of the joint TES and OMI ozone near-surface ozone estimates (surface to $700 \mathrm{hPa}$ ) to ozonesondes shows enhanced capability in quantifying near-surface ozone variations over TES or OMI estimates alone. However, improvements in vertical resolution are not as large as theoretically shown by Worden et al. (2007) due to the need to retrieve ancillary parameters. To further improve the retrievals, we need to reduce correlations between ozone concentration and ancillary parameters, improve instrumental calibration, and perform more accurate radiative transfer calculations. Additional comparisons between OMI/TES profile estimates and ozonesondes are desirable to gain more confidence in these statistics.

Acknowledgements. We are grateful to Ruud Dirksen, Robert Voors, and Marcel Dobbers for providing OMI spectral slit function data and Braak Remco at Royal Netherlands Meteorological Institute for providing information on OMI L1b data. We thank Annmarie Eldering, Stanley Sander, Robert Herman, and Alyn Lambert for helpful discussions. We thank the World Ozone Data Centre for making the routine sonde data accessible. We thank the editor and reviewers for helpful suggestions. The research described in this paper was carried out at the Jet Propulsion Laboratory, California Institute of Technology, under a contract with the National Aeronautics and Space Administration. Research at the Smithsonian Astrophysical Observatory was 
supported by the National Aeronautics and Space Administration and by the Smithsonian Institution. The JPL authors' copyright for this publication is held by the California Institute of Technology. Government Sponsorship acknowledged.

Edited by: W. Lahoz

\section{References}

Acarreta, J. R., De Haan, J. F., and Stammes, P.: Cloud pressure retrieval using the $\mathrm{O}_{2}-\mathrm{O}_{2}$ absorption band at $477 \mathrm{~nm}$, J. Geophys. Res., 109, D05204, doi:10.1029/2003JD003915, 2004.

Akimoto, H., Irie, H., Kasai, Y., Kanaya, Y., Kita, K., Koike, M., Kondo, Y., Nakazawa, T., and Hayashida, S.: Planning a geostationary atmospheric observation satellite, Commission on the Atmospheric Observation Satellite of the Japan Society of Atmospheric Chemistry (http://www.stelab.nagoya-u.ac.jp/ste-www1/ div1/taikiken/eisei/eisei2.pdf, Japanese version only), 2008.

Bailey, P. L., Edwards, D. P., Gille, J. C., Lyjak, L. V., Massie, S. T., Roche, A. E., Kumer, J. B., Mergenthaler, J. L., Connor, B. J., Gunson, M. R., Margitan, J. J., McDermid, I. S., and McGee, T. J.: Comparison of cryogenic limb array etalon spectrometer (CLAES) ozone observations with correlative measurements, J. Geophys. Res., 101, 9737-9756, doi:10.1029/95JD03614, 1996.

Beer, R.: Glavich, T. A., and Rider, D. M.: Tropospheric emission spectrometer for the Earth Observing System's Aura satellite, Appl. Opt., 40, 2356-2367, doi:10.1364/AO.40.002356, 2001.

Beer, R. L: TES on the Aura mission: scientific objectives, measurements, and analysis overview, IEEE Transactions on Geoscience and remote sensing, 44, 1102-1105, 2006.

Bell, M. L., Peng, R. D., and Dominici, F.: The Exposure-response curve for ozone and risk of mortality and the adequacy of current ozone regulations, Environ. Health Perspect., 114, 532-536, 2006.

Bernath, P. F., McElroy, C. T., Abrams, M. C., Boone, C. D., Butler, M., Camy-Peyret, C., Carleer, M., Clerbaux, C., Coheur, P. F., Colin, R., DeCola, P., DeMazière, M., Drummond, J. R., Dufour, D., Evans, W. F. J., Fast, H., Fussen, D., Gilbert, K., Jennings, D. E., Llewellyn, E. J., Lowe, R. P., Mahieu, E., McConnell, J. C., McHugh, M., McLeod, S. D., Michaud, R., Midwinter, C., Nassar, R., Nichitiu, F., Nowlan, C., Rinsland, C. P., Rochon, Y. J., Rowlands, N., Semeniuk, K., Simon, P., Skelton, R., Sloan, J. J., Soucy, M.-A., Strong, K., Tremblay, P., Turnbull, D., Walker, K. A., Walkty, I., Wardle, D. A., Wehrle, V., Zander, R., and Zou, J.: Atmospheric Chemistry Experiment (ACE): Mission overview, Geophys. Res. Lett., 32, L15S01, doi:10.1029/2005GL022386, 2005.

Bhartia, P. K., McPeters, R. D., Mateer, C. L., Flynn, L. E., and Wellemeyer, C.: Algorithm for the estimation of vertical ozone profiles from the backscattered ultraviolet technique, J. Geophys. Res., 101, 18793-18806, doi:10.1029/96JD01165, 1996.

Blom, C. E., Fischer, H., Glatthor, N., Gulde, T., Höpfner, M., and Piesch, C.: Spatial and temporal variability of $\mathrm{ClONO}_{2}, \mathrm{HNO}_{3}$, and $\mathrm{O}_{3}$ in the Arctic winter of 1992/1993 as obtained by airborne infrared emission spectroscopy, J. Geophys. Res., 100, 91019114, doi:10.1029/94JD02954, 1995.

Boone, C. D., Nassar, R., Walker, K. A., Rochon, Y., McLeod, S. D., Rinsland, C. P., and Bernath, P. F.: Retrievals for the atmo- spheric chemistry experiment Fourier-transform spectrometer, Appl. Opt., 44, 7218-7231, doi:10.1364/AO.44.007218, 2005.

Bowman, K. W., Steck, T., Worden, H. M., Worden, J., Clough, S., and Rodgers, C. D.: Capturing time and vertical variability of Tropospheric ozone: a study using TES nadir retrieval, J. Geophys. Res., 107, ACH21-1-ACH21-11, doi:10.1029/2002JD002150, 2002.

Bowman, K. W., Rodgers, C. D., Kulawik, S. S., Worden, J., Sarkissian, E., Osterman, G., Steck, T., Lou, M., Eldering, A., Shephard, M., Worden, H., Lampel, M., Clough, S., Brown, P., Rinsland, C., Gunson, M., and Beer, R.: Tropospheric Emission Spectrometer: retrieval method and error analysis, IEEE Trans. Geosci. Remote Sens., 44, 1297-1307, 2006.

Boxe, C. S., Worden, J. R., Bowman, K. W., Kulawik, S. S., Neu, J. L., Ford, W. C., Osterman, G. B., Herman, R. L., Eldering, A., Tarasick, D. W., Thompson, A. M., Doughty, D. C., Hoffmann, M. R., and Oltmans, S. J.: Validation of northern latitude Tropospheric Emission Spectrometer stare ozone profiles with ARC-IONS sondes during ARCTAS: sensitivity, bias and error analysis, Atmos. Chem. Phys., 10, 9901-9914, doi:10.5194/acp10-9901-2010, 2010.

Brasseur, G. P., Hauglustaine, D. A., Walters, S., Rasch, P. J., Muller, J. F., Granier, C., and Tie, X. X.: MOZART, a global chemical transport model for ozone and related chemical tracers 1. Model description, J. Geophys. Res., 103, 28265-28289, doi:10.1029/98JD02397, 1998.

Brion, J., Chakir, A., Daumont, D., and Malicet, J.: Highresolution laboratory absorption cross section of $\mathrm{O}_{3}$ : Temperature effect, Chem. Phys. Lett., 213, 610-612, doi:10.1016/00092614(93)89169-I, 1993.

Browell, E. V., Carter, A. F., Shipley, S. T., Allen, R. J., Butler, C. F., Mayo, M. N., Siviter Jr., J. H., and Hall, W. M.: NASA Multipurpose Airborne DIAL system and measurements of ozone and aerosol profiles, Appl. Opt., 22, 522-534, doi:10.1364/AO.22.000522, 1983.

Brühl, C., Drayson, S. R., Russell III, J. M., Crutzen, P. J., McInerney, J. M., Purcell, P. N., Claude, H., Gernandt, H., McGee, T. J., McDermid, I. S., and Gunson, M. R.: Halogen Occultation Experiment ozone channel validation, J. Geophys. Res., 101, 10217-10240, doi:10.1029/95JD02031, 1996.

Cai, Z., Liu, Y., Liu, X., Chance, K. V., Nowlan, C. R., Lang, R., Munro, R., and Suleiman, R.: Characterization and correction of Global Ozone Monitoring Experiment 2 ultraviolet measurements and application to ozone profile retrievals, J. Geophys. Res., 117, D07305, doi:10.1029/2011JD017096, 2012.

Chance, K. V., Burrows, J. P., Perner, D., and Scheider, W.: Satellite measurements of atmospheric ozone profiles, including tropospheric ozone, from ultraviolet/visible measurements in the nadir geometry: a potential method, J. Quant. Spectrosc. Radiat. Transfer, 57, 467-476, doi:10.1016/S0022-4073(96)00157-4, 1997.

Clarmann, T. V., Oelhaf, H., and Fischer, H.: Retrieval of atmospheric $\mathrm{O}_{3}, \mathrm{HNO}_{3}, \mathrm{CFC}-11$, and $\mathrm{CFC}-12$ profiles from MIPAS-B-89 limb emission spectra, Appl. Opt., 32, 6808-6817, doi:10.1364/AO.32.006808, 1993.

Clerbaux, C., Turquety, S., and Coheur, P. F.: Infrared remote sensing of atmospheric composition and air quality: Towards operational applications, Comptes Rendus Geosciences, 342, 349356, doi:10.1016/j.crte.2009.09.010, 2010. 
Clough, S. A., Shephard, M. W., Worden, J., Brown, P. D., Worden, H. M., Luo, M., Rodgers, C. D., Rinsland, C. P., Goldman, A., Brown, L., Kulawik, S. S., Eldering, A., Lampel, M. C., Osterman, G., Beer, R., Bowman, K., Cady-Pereira, K. E., and Mlawer, E. J.: Forward model and Jacobians for Tropospheric Emission Spectrometer retrievals, IEEE Trans. Geosci. Remote Sens., 44, 1308-1323, 2006.

Cuesta, J., Eremenko, M., Liu, X., Dufour, G., Cai, Z., Höpfner, M., von Clarmann, T., Sellitto, P., Foret, G., Gaubert, B., Beekmann, M., Orphal, J., Chance, K., Spurr, R., and Flaud, J.-M.: Satellite observation of lowermost tropospheric ozone by multispectral synergism of IASI thermal infrared and GOME-2 ultraviolet measurements, Atmos. Chem. Phys. Discuss., 13, 29552995, doi:10.5194/acpd-13-2955-2013, 2013.

Dobber, M. R., Dirksen, R. J., Levelt, P. F., van den Oord, G. H. J., Voors, R. H. M., Kleipool, Q., Jaross, G., Kowalewski, M., Hilsenrath, E., Leppelmeier, G. W., J. de Vries, Dierssen, W., and Rozemeijer, N. C.: Ozone Monitoring Instrument calibration, IEEE Trans. Geosci. Remote Sens., 44, 1209-1238, 2006.

Eldering, A., Kulawik, S. S., Worden, J., Bowman, K., and Osterman, G.: Implementation of cloud retrievals for TES atmospheric retrievals: 2 . Characterization of cloud top pressure and effective optical depth retrievals, J. Geophys. Res., 113, D16S37, doi:10.1029/2007JD008858, 2008.

Eichmann, K.-U., Kaiser, J. W., von Savigny, C., Rozanov, A., Rozanov, V. V., Bovensmann, H., von Konig, M., and Burrows, J. P.: SCIAMACHY limb measurements in the UV/Vis spectral region: first results, Adv. Space Res., 34, 775-779, doi:10.1016/j.asr.2003.05.057, 2004.

European Space Agency: GMES sentinels 4 and 5. Mission Requirements Document EOP-SMA/1507, 87, 2007.

Fishman, J., Iraci, L.T., Al-Saadi, J., Chance, K., Chavez, F., Chin, M., Coble, P., Davis, C., DiGiacomo, P.M., Edwards, D., Eldering, A., Goes, J., Herman, J., Hu, C., Jacob, D., Jordan, C., Kawa, S.R., Key, R., Liu, X., Lohrenz, S., Mannino, A., Natraj, V., Neil, D., Neu, J., Newchurch, M., Pickering, K., Salisbury, J., Sosik, H., Subramaniam, A., Tzortziou, M., Wang, J., and Wang, M.: The United States' next generation of atmospheric composition and coastal ecosystem measurements: NASA's Geostationary Coastal and Air Pollution Events (GEO-CAPE) mission, B. Am. Meteorol. Soc., 93, 1547-1566, doi:10.1175/BAMS-D-11$00201.1,2012$.

Flaud, J.-M., Piccolo, C., Carli, B., Perrin, A., Coudert, L. H., Teffo, J.-L., and Brown, L. R.: Molecular line parameters for the MIPAS (Michelson Interferometer for Passive Atmospheric Sounding) experiment (in Russian and English), Atmos. Oceanic Opt., 16, 172-182, 2003.

Götz, F. W. P., Meetham, A. R., and Dobson, G. M. B.: The vertical distribution of ozone in the atmosphere, Proc. Roy. Soc. London, A145, 416-446, 1934.

Gunson, M. R., Farmer, C. B., Norton, R. H., Zander, R., Rinsland, C. P., Shaw, J. H., and Gao, B. C.: Measurements of $\mathrm{CH}_{4}, \mathrm{~N}_{2} \mathrm{O}$, $\mathrm{CO}, \mathrm{H}_{2} \mathrm{O}$, and $\mathrm{O}_{3}$ in the middle atmosphere by the Atmospheric Trace Molecule Spectroscopy experiment on Spacelab 3, J. Geophys. Res., 95, 13867-13882, doi:10.1029/JD095iD09p13867, 1990.

Hamdouni, A., Barbe, A., Demoulin, P., and Zander, R.: Retrieval of ozone vertical column amounts from ground-based high resolution infrared solar spectra, J. Quant. Spectrosc. Radiat. Transfer,
57, 11-22, doi:10.1016/S0022-4073(96)00112-4, 1997.

Hatfield, J., Boote, K., Fay, P., Hahn, L., Izaurralde, C., Kimball, B. A., Mader, T., Morgan, J., Ort D., Polley, W., Thomson, A., and Wolfe, D.: Agriculture, in: The Effects of Climate Change on Agriculture, Land Resources, Water Resources, and Biodiversity in the United States, edited by: Backlund, P., Janetos, A., Schimel, D., Hatfield, J., Boote, K., Fay, P., Hahn, L., Izaurralde, C., Kimball, B. A., Mader, T., Morgan, J., Ort, D., Polley, W., Thomson, A., Wolfe, D., Ryan, M. G., Archer, S. R., Birdsey, R., Dahm, C., Heath, L., Hicke, J., Hollinger, D., Huxman, T., Okin, G., Oren, R., Randerson, J., Schlesinger, W., Lettenmaier, D., Major, D., Poff L., Running, S., Hansen, L., Inouye, D., Kelly, B. P., Meyerson, L., Peterson, B., and Shaw, R., Synthesis and Assessment Product 4.3. U.S. Department of Agriculture, Washington, DC, 21-74, 2008.

Hoogen, R., Rozanov, V. V., and Burrows, J. P.: Ozone profiles from GOME satellite data: Algorithm description and first validation, J. Geophys. Res., 104, 8263-8280, doi:10.1029/1998JD100093, 1999.

Ingmann, P., Veihelmann, B., Langen, J., Lamarre, D., Stark, H., and Courrèges-Lacoste, G. B.: Requirements for the GMES Atmosphere Service and ESA's implementation concept: Sentinels-4/-5 and -5p, Remote Sens. Environ., 120, 58-69, doi:10.1016/j.rse.2012.01.023, 2012.

Jerrett, M., Burnett, R. T., Pope III, C. A., Ito, K., Thurston, G., Krewski, D., Shi, Y., Calle, E., and Thun, M.: Long-Term Ozone Exposure and Mortality, N. Engl. J. Med., 360, 1085-1095, 2009.

Joiner, J. and Vasilkov, A. P.: First results from the OMI rotational raman scattering cloud pressure algorithm, IEEE T. Geosci. Remote, 44, 1272-1282, doi:10.1109/TGRS.2005.861385, 2006.

Kalnay, E., Kanamitsu, M., Kistler, R., Collins, W., Deaven, D., Gandin, L., Iredell, M., Saha, S., White, G.,Woollen, J., Zhu, Y., Chelliah, M., Ebisuzaki, W., Higgins, W., Janowiak, J., Mo, K. C., Ropelewski, C., Wang, J., Leetmaa, A., Reynolds, R., Jenne, R., and Joseph, D.: The NCEP/NCAR 40-year reanalysis project, B. Am. Meteorol. Soc., 77, 437-471, 1996.

Kleipool, Q. L., Dobber, M. R., Haan, J. F. de, and Levelt, P. F.: Earth surface reflectance climatology from 3 years of OMI data, J. Geophys. Res., 113, D18308, doi:10.1029/2008JD010290, 2008.

Komhyr, W. D., Barnes, R. A., Brothers, G. B., Lathrop, J. A., and Opperman, D. P.: Electrochemical concentration cell ozonesonde performance evaluation during STOIC 1989, J. Geophys. Res., 100, 9231-9244, doi:10.1029/94JD02175, 1995.

Kroon, M., de Haan, J. F., Veefkind, J. P., Froidevaux, L., Wang, R., Kivi, R., and Hakkarainen, J. J.: Validation of operational ozone profiles from the Ozone Monitoring Instrument, J. Geophys. Res., 116, D18305, doi:10.1029/2010JD015100, 2011.

Kuai, L., Worden, J., Kulawik, S., Bowman, K., Lee, M., Biraud, S. C., Abshire, J. B., Wofsy, S. C., Natraj, V., Frankenberg, C., Wunch, D., Connor, B., Miller, C., Roehl, C., Shia, R.-L., and Yung, Y.: Profiling tropospheric $\mathrm{CO}_{2}$ using Aura TES and TCCON instruments, Atmos. Meas. Tech., 6, 63-79, doi:10.5194/amt-6-63-2013, 2013.

Kulawik, S. S., Worden, H., Osterman, G., Luo, M., Beer, R., Kinnison, D. E., Bowman, K. W., Worden, J., Eldering, A., Lampel, M., Steck, T., and Rodgers, C. D.: TES Atmospheric Profile Retrieval Characterization: An Orbit of Simulated Observations, IEEE Trans. Geosci. Remote Sens., 44, 1324-1333, 2006a. 
Kulawik, S. S., Worden, J., Eldering, A., Bowman, K., Gunson, M., Osterman, G. B., Zhang, L., Clough, S., Shephard, M. W., and Beer, R.: Implementation of cloud retrievals for Tropospheric Emission Spectrometer (TES) atmospheric retrievals: part 1. Description and characterization of errors on trace gas retrievals, J. Geophys. Res., 111, D24204, doi:10.1029/2005JD006733, 2006 .

Kulawik, S. S., Osterman, G., and Jones, D.: Calculation of altitudedependent Tikhonov constraints for TES nadir retrievals, IEEE Trans. Geosci. Remote Sens., 44, 1334-1342, 2006c.

Kulawik, S. S., Liu, X., Worden, J. R., Chance, K., Bowman, K., Worden, H., and the TES team: Optimally combining ozone from Tropospheric Emission Spectrometer (TES) and Ozone Monitoring Instrument (OMI) data. Eos, Transactions, American Geophysical Union 88(52), Fall Meeting Supplement, Abstract A33C-1403, 2007.

Lahoz, W. A., Peuch, V.-H., Orphal, J., Attié, J.-L., Chance, K., Liu, X., Edwards, D., Elbern, H., Flaud, J.-M., Claeyman, M., and El Amraoui, L.: Monitoring air quality from space: The case for the geostationary platform, B. Am. Meteorol. Soc., 93, 221-233, doi:10.1175/BAMS-D-11-00045.1, 2012.

Landgraf, J. and Hasekamp, O. P.: Retrieval of tropospheric ozone: The synergistic use of thermal infrared emission and ultraviolet reflectivity measurements from space, J. Geophys. Res., 112, D08310, doi:10.1029/2006JD008097, 2007.

Lee, S., Hong, Y., Song, C.-K., Lee, J., Choi, W.-J., Kim, D., Moon, K.-J., and Kim, J.: Plan of Korean Geostationary Environment Satellite over Asia-Pacific region: Geophysical Research Abstracts, Vol. 12, EGU2010-7595-1, EGU General Assembly, 2010.

Liu, X., Chance, K., Sioris, C. E., Spurr, R. J. D., Kurosu, T. P., Martin, R. V., and Newchurch, M. J.: Ozone profile and tropospheric ozone retrievals from the Global Ozone Monitoring Experiment: Algorithm description and validation, J. Geophys. Res., 110, D20307, doi:10.1029/2005JD006240, 2005.

Liu, X., Chance, K., Sioris, C. E., Kurosu, T. P., Spurr, R. J. D., Martin, R. V., Fu, T. M, Logan, J. A., Jacob, D. J., Palmer, P. I., Newchurch, M. J., Megretskaia, I. A., and Chatfield, R. B.: First directly retrieved global distribution of tropospheric column ozone from GOME: Comparison to the GEOS-Chem model, J. Geophys. Res., 111, D02308, doi:10.1029/2005JD006564, 2006.

Liu, X., Chance, K., Sioris, C. E., and Kurosu, T. P.: Impact of using different ozone cross sections on ozone profile retrievals from Global Ozone Monitoring Experiment (GOME) ultraviolet measurements, Atmos. Chem. Phys., 7, 3571-3578, doi:10.5194/acp7-3571-2007, 2007.

Liu, X., Bhartia, P. K., Chance, K., Spurr, R. J. D., and Kurosu, T. P.: Ozone profile retrievals from the Ozone Monitoring Instrument, Atmos. Chem. Phys., 10, 2521-2537, doi:10.5194/acp-10-25212010, 2010a.

Liu, X., Bhartia, P. K., Chance, K., Froidevaux, L., Spurr, R. J. D., and Kurosu, T. P.: Validation of Ozone Monitoring Instrument (OMI) ozone profiles and stratospheric ozone columns with Microwave Limb Sounder (MLS) measurements, Atmos. Chem. Phys., 10, 2539-2549, doi:10.5194/acp-10-2539-2010, 2010 b.

Livesey, N. J., Filipiak, M. J., Froidevaux, L., Read, W. G., Lambert, A., Santee, M. L., Jiang, J. H., Pumphrey, H. C., Waters, J. W., Cofield, R. E., Cuddy, D. T., Daffer, W. H., Drouin, B. J., Fuller, R. A., Jarnot, R. F., Jiang, Y. B., Knosp, B. W., Li,
Q. B., Perun, V. S., Schwartz, M. J., Snyder, W. V., Stek, P. C., Thurstans, R. P., Wagner, P. A., Avery, M., Browell, E. V., Cammas, J. P., Christensen, L. E., Diskin, G. S., Gao, R. S., Jost, H. J., Loewenstein, M., Lopez, J. D., Nédélec, P., Osterman, G. B., Sachse, G. W., and Webster, C. R.: Validation of Aura Microwave Limb Sounder $\mathrm{O}_{3}$ and $\mathrm{CO}$ observations in the upper troposphere and lower stratosphere, J. Geophys. Res., 113, D15S02, doi:10.1029/2007JD008805, 2008.

McConnell, J., McElroy, C. T., Solheim, B., Sioris, C., Evans, W., Buijs, H., Roux, M., Rahnama, P., Walker, K., Jones, D., Garand, L., Nassar, R., Martin, R., O’Neill, N., Bergeron, M., and the PCW/PHEMOS Science Team: A quasi-geostationary view of the Arctic and environs: PCW/PHEMOS for Arctic weather, climate and air quality, EUMETSAT meteorological satellite conference, Oslo, Norway, 2011.

McDermid, I. S., Beyerle, G., Haner, D. A., and Leblanc, T.: Redesign and improved performance of the tropospheric ozone lidar at the Jet Propulsion Laboratory Table Mountain Facility, Appl. Opt., 41, 7550-7555, doi:10.1364/AO.41.007550, 2002.

McPeters, R. D., Janz, S. J., Hilsenrath, E., Brown, T. L., Flittner, D. E., and Heath, D. F.: The retrieval of $\mathrm{O}_{3}$ profiles from limb scatter measurements: Results from the Shuttle Ozone Limb Sounding Experiment, Geophys. Res. Lett., 27, 25972600, doi:10.1029/1999GL011342, 2000.

McPeters, R. D., Labow, G. J., and Logan, J. A.: Ozone climatological profiles for satellite retrieval algorithms, J. Geophys. Res., 112, D05308, doi:10.1029/2005JD006823, 2007.

Molod, A., Takacs L., Suarez, M., Bacmeister, J., Song, I., and Eichmann, A.: The GEOS-5 Atmospheric General Circulation Model: Mean Climate and Development from MERRA to Fortuna, Tech. Rep. 28, Goddard Space Flight Center, NASA/TM2012-104606, 2012.

Munro, R., Siddans, R., Reburn, W. J., and Kerridge, B.: Direct measurement of tropospheric ozone from space, Nature, 392, 168-171, doi:10.1038/32392, 1998.

National Research Council, Committee on Earth Science and Applications from Space: A Community Assessment and Strategy for the Future: Earth Science and Applications from Space: National Imperatives for the Next Decade and beyond, National Academies Press, Washington DC, 2007.

Natraj, V., Liu, X., Kulawik, S., Chance, K., Chatfield, R., Edwards, D., Eldering, A., Francis, G., Kurosu, T., Pickering, K., Spurr, R., and Worden, H.: Multi-spectral sensitivity studies for the retrieval of tropospheric and lowermost tropospheric ozone from simulated clear-sky GEO-CAPE measurements, Atmos. Environ., 45, 7151-7165, doi:10.1016/j.atmosenv.2011.09.014, 2011.

Park, M., Randel, W. J., Kinnison, D. E., Garcia, R. R., and Choi, W.: Seasonal variation of methane, water vapor, and nitrogen oxides near the tropopause: Satellite observations and model simulations, J. Geophys. Res., Atmos., 109, D03302, doi:10.1029/2003JD003706, 2004.

Petropavlovskikh, I., Bhartia, P. K., and DeLuisi, J.: New Umkehr ozone profile retrieval algorithm optimized for climatological studies, Geophys. Res. Lett., 32, L16808, doi:10.1029/2005GL023323, 2005.

Picquet-Varrault, B., Orphal, J., Doussin, J.-F., Carlier, P., and Flaud, J.-M.: Laboratory intercomparison of the ozone absorption coefficients in the mid-infrared $(10 \mu \mathrm{m})$ and ultraviolet (300$350 \mathrm{~nm}$ ) spectral regions, J. Phys. Chem. A., 109, 1008-1014, 
doi:10.1021/jp0405411, 2005.

Pougatchev, N. S., Connor, B. J., and Rinsland, C. P.: Infrared measurements of the ozone vertical distribution above Kitt Peak, J. Geophys. Res., 100, 16689-16697, doi:10.1029/95JD01296, 1995.

Riese, M., Spang, R., Preusse, P., Ern, M., Jarisch, M., Offermann, D., and Grossmann, K.-U.: Cryogenic Infrared Spectrometers and Telescopes for the Atmosphere (CRISTA) data processing and atmospheric temperature and trace gas retrieval, J. Geophys. Res., 104, 16349-16367, doi:10.1029/1999JD900274, 1999.

Rodgers, C. D.: Inverse methods for atmospheric sounding: Theory and practice, Word Scientific Publishing, Singapore, 2000.

Rothman, L. S., Jacquemart, D., Barbe, A., Benner, D. C., Birk, M., Brown, L. R., Carleer, M. R., Chackerian Jr., C., Chance, K., Coudert, L. H., Dana, V., Devi, V. M., Flaud, J.-M., Gamache, R. R., Goldman, A., Hartmann, J.-M., Jucks, K. W., Maki, A. G., Mandin, J.-Y., Massie, S. T., Orphal, J., Perrin, A., Rinsland, C. P., Smith, M. A. H., Tennyson, J., Tolchenov, R. N., Toth, R. A., Vander Auwera, J., Varanasi, P., and Wagner, G.: The HITRAN 2004 molecular spectroscopic database, J. Quant. Spectrosc. Radiat. Transfer, 96, 139-204, doi:10.1016/j.jqsrt.2004.10.008, 2005.

Rothman, L. S., Gordon, I. E., Barbe, A., Benner, C., Bernath, P. F., Birk, M., Boudon, V., Brown, L. R., Campargue, A., Champion, J. P., Chance, K., Coudert, L. H., Dana, V., Devi, V. M., Fally, S., Flaud, J. M., Gamache, R. R., Goldman, A., Jacquemart, D., Kleiner, I., Lacome, N., Lafferty, W. J., Mandin, J. Y., Massie, S. T., Mikhailenko, S. N., Miller, C. E., Moazzen-Ahmadi, N., Naumenko, O. V., Nikitin, A. V., Orphal, J., Perevalov, V. I., Perrin, A., Predoi Cross, A., Rinsland, C. P., Rotger, M., Simecková, M., Smith, M. A. H., Sung, K., Tashkun, S. A., Tennyson, J., Toth, R. A., Vandaele, A. C., and Auwera, J. V.: The HITRAN 2008 molecular spectroscopic database, J. Quant. Spectrosc. Radiat. Transfer, 110, 533-572, doi:10.1016/j.jqsrt.2009.02.013, 2009.

Sellitto, P., Frate, F. D., Solimini, D., and Casadio, S.: Tropospheric Ozone Column Retrieval From ESA-Envisat SCIAMACHY Nadir UV/VIS Radiance Measurements by Means of a Neural Network Algorithm, IEEE T. Geosci. Remote Sens., 50, 998-1011, 2012a.

Sellitto, P., Noia, A. D., Frate, F. D., Burini, A., Casadio, S., and Solimini, D.: On the role of visible radiation in ozone pro?le retrieval from nadir UV/VIS satellite measurements: An experiment with neural network algorithms inverting SCIAMACHY data, J. Quant. Spectrosc. Ra. Transfer, 113, 1429-1436, 2012b.

Sioris, C. E. and Evans, W. F. J.: Impact of rotational Raman scattering in the $\mathrm{O}_{2}$ A band, Geophys. Res. Lett., 27, 4085-4088, doi:10.1029/2000GL012231, 2000.

Spurr, R. J. D.: VLIDORT: A linearized pseudo-spherical vector discrete ordinate radiative transfer code for forward model and retrieval studies in multilayer multiple scattering media, J. Quant. Spectrosc. Ra. Transfer, 102, 316-342, doi:10.1016/j.jqsrt.2006.05.005, 2006.

Spurr, R. J. D.: Linearized pseudo-spherical scalar and vector discrete ordinate radiative transfer models for use in remote sensing retrieval problems, in: Light Scattering Reviews, edited by: Kokhanovsky, A., Springer, New York, Part II, 229-275, doi:10.1007/978-3-540-48546-9_7, 2008.

Steck, T.: Methods for determining regularization for atmospheric retrieval problems, Appl. Opt., 41, 1788-1797,
doi:10.1364/AO.41.001788, 2002.

Toon, G. C., Farmer, C. B., Lowes, L. L., Schaper, P. W., Blavier, J.-F., and Norton, R. H.: Infrared Aircraft Measurements of Stratospheric Composition over Antarctica during September 1987, J. Geophys. Res., 94, 16571-16596, doi:10.1029/JD094iD14p16571, 1989.

Toon, G. C., Sen, B., Blavier, J. F., Sasano, Y., Yokota, T., Kanzawa, H., Ogawa, T., Suzuki, M., and Shibasaki, K.: Comparison of ILAS and MkIV profiles of atmospheric trace gases measured above Alaska in May 1997, J. Geophys. Res., 107, 8211, doi:10.1029/2001JD000640, 2002.

Tzortziou, M., Krotkov, N., Cede, A., Herman, J., and Vasilkov, A.: New technique for retrieval of tropospheric and stratospheric ozone profiles using sky radiance measurements at multiple view angles: application to a brewer spectrometer, J. Geophys. Res., 113, D06304, doi:10.1029/2007JD009093, 2008.

van Peet, J. C. A., van $\operatorname{der}$ A, R. J., de Laat, A. T. J., Tuinder, O. N. E., König-Langlo, G., and Wittig, J.: Height resolved ozone hole structure as observed by the Global Ozone Monitoring Experiment-2, Geophys. Res. Lett., 36, L11816, doi:10.1029/2009GL038603, 2009.

von Savigny, C., Haley, C. S., Sioris, C. E., McDade, I. C., Llewellyn, E. J., Degenstein, D., Evans, W. F. J., Gattinger, R. L., Griffioen, E., Kyrölä, E., Lloyd, N. D., McConnell, J. C., McLinden, C. A., Mégie, G., Murtagh, D. P., Solheim, B., and Strong, K.: Stratospheric ozone profiles retrieved from limb scattered sunlight radiance spectra measured by the OSIRIS instrument on the Odin satellite, Geophys. Res. Lett., 30, 1755, doi:10.1029/2002GL016401, 2003.

Vasilkov, A., Joiner, J., Spurr, R., Bhartia, P. K., Levelt, P., and Stephens, G.: Evaluation of the OMI cloud pressures derived from rotational Raman scattering by comparisons with other satellite data and radiative transfer simulations, J. Geophys. Res., 113, D15S19, doi:10.1029/2007JD008689, 2008.

Wagner, G., Birk, M., Schreier, F., and Flaud, J.-M.: Spectroscopic database for ozone in the fundamental spectral regions, J. Geophys. Res., 107, 4626, doi:10.1029/2001JD000818, 2002.

Weidner, F., Bösch, H., Bovensmann, H., Burrows, J. P., Butz, A., Camy-Peyret, C., Dorf, M., Gerilowski, K., Gurlit, W., Platt, U., von Friedeburg, C., Wagner, T., and Pfeilsticker, K.: Balloonborne limb profiling of $\mathrm{UV} / \mathrm{vis}$ skylight radiances, $\mathrm{O}_{3}, \mathrm{NO}_{2}$, and $\mathrm{BrO}$ : technical set-up and validation of the method, Atmos. Chem. Phys., 5, 1409-1422, doi:10.5194/acp-5-1409-2005, 2005.

Weinhold, B.: Ozone nation: EPA standard panned by the people, Environ. Health Perspect., 116, A302-A305, 2008.

Worden, H. M, Beer, R., Bowman, K. W., Fisher, B., Luo, M., Rider, D., Sarkissian, E., Tremblay, D., and Zong, J.: TES Level 1 Algorithms: Interferogram Processing, Geolocation, Radiometric, and Spectral Calibration, IEEE Trans. Geosci. Remote Sens., 44, 1288-1296, 2006.

Worden, H. M., Logan, J. A., Worden, J. R., Beer, R., Bowman, K., Clough, S. A., Eldering, A., Fisher, B. M., Gunson, M. R., Herman, R. L., Kulawik, S. S., Lampel, M. C., Luo, M., Megretskaia, I. A., Osterman, G. B., and Shephard M. W.: Comparisons of Tropospheric Emission Spectrometer (TES) ozone profiles to ozonesondes: Methods and initial results, J. Geophys. Res., 112, D03309, doi:10.1029/2006JD007258, 2007a. 
Worden, J., Liu, X., Bowman, K., Chance, K., Beer, R., Eldering, A., Gunson, M., and Worden, H.: Improved tropospheric ozone profile retrievals using OMI and TES radiances, Geophys. Res. Lett., 34, L01809, doi:10.1029/2006GL027806, 2007b.
Worden, H. M., Deeter, M. N., Edwards, D. P., Gille, J. C., Drummond, J. R., and Nédélec, P.: Observations of near-surface carbon monoxide from space using MOPITT multispectral retrievals, J. Geophys. Res., 115, D18314, doi:10.1029/2010JD014242, 2010.

World Health Organization: Health Aspects of Air Pollution with Particulate Matter, Ozone and Nitrogen Dioxide, Bonn, Germany, 13-15 January 2003. 